\title{
Review \\ Phenolic Acids and Prevention of Cognitive Decline: Polyphenols with a Neuroprotective Role in Cognitive Disorders and Alzheimer's Disease
}

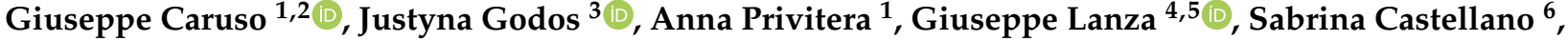 \\ Alessio Chillemi ${ }^{3}$, Oliviero Bruni ${ }^{7}\left(\mathbb{D}\right.$, Raffaele Ferri ${ }^{8}\left(\mathbb{D}\right.$, Filippo Caraci ${ }^{1,2, *}$ and Giuseppe Grosso ${ }^{3}{ }^{(1)}$
}

Citation: Caruso, G.; Godos, J.; Privitera, A.; Lanza, G.; Castellano, S.; Chillemi, A.; Bruni, O.; Ferri, R.; Caraci, F.; Grosso, G. Phenolic Acids and Prevention of Cognitive Decline: Polyphenols with a Neuroprotective Role in Cognitive Disorders and Alzheimer's Disease. Nutrients 2022, 14, 819. https://doi.org/10.3390/ nu14040819

Academic Editor: Kentaro Matsuzaki

Received: 30 December 2021 Accepted: 11 February 2022 Published: 15 February 2022

Publisher's Note: MDPI stays neutral with regard to jurisdictional claims in published maps and institutional affiliations.

Copyright: (C) 2022 by the authors. Licensee MDPI, Basel, Switzerland. This article is an open access article distributed under the terms and conditions of the Creative Commons Attribution (CC BY) license (https:// creativecommons.org/licenses/by/ $4.0 /)$.
1 Department of Drug and Health Sciences, University of Catania, 95125 Catania, Italy; forgiuseppecaruso@gmail.com (G.C.); annaprivitera01@gmail.com (A.P.)

2 Research Operative Unit of Neuropharmacology and Translational Neurosciences, Oasi Research Institute-IRCCS, 94018 Troina, Italy

3 Department of Biomedical and Biotechnological Sciences, University of Catania, 95123 Catania, Italy; justyna.godos@gmail.com (J.G.); alessio.chillemi90@gmail.com (A.C.); giuseppe.grosso@unict.it (G.G.)

4 Clinical Neurophysiology Research Unit, Oasi Research Institute-IRCCS, 94018 Troina, Italy; glanza@oasi.en.it

5 Department of Surgery and Medical-Surgical Specialties, University of Catania, 95123 Catania, Italy

6 Department of Educational Sciences, University of Catania, 95124 Catania, Italy; sabrina.castellano@unict.it

7 Department of Developmental and Social Psychology, Sapienza University, 00185 Rome, Italy; oliviero.bruni@uniroma1.it

8 Sleep Research Centre, Department of Neurology IC, Oasi Research Institute-IRCCS, 94018 Troina, Italy; rferri@oasi.en.it

* Correspondence: fcaraci@unict.it

Abstract: Cognitive impairment, also known as cognitive decline, can occur gradually or suddenly and can be temporary or more permanent. It represents an increasingly important public health problem and can depend on normal aging or be linked to different neurodegenerative disorders, including Alzheimer's disease (AD). It is now well-established that lifestyle factors including dietary patterns play an important role in healthy aging as well as in the prevention of cognitive decline in later life. Among the natural compounds, dietary polyphenols including phenolic acids have been recently the focus of major attention, with their supplementation being associated with better cognitive status and prevention of cognitive decline. Despite their therapeutic potential, human studies investigating the relation between phenolic acids intake and cognitive outcomes are rather scarce. In this review, we provide preclinical evidence that different dietary polyphenols such as rosmarinic acid, ellagic acid, and cinnamic aldehyde can exert neuroprotective and pro-cognitive activities through different molecular mechanisms including the modulation of pro-oxidant and antioxidant machinery as well as inflammatory status. Future and more numerous in vivo studies are needed to strengthen the promising results obtained at the preclinical level. Despite the excellent pharmacokinetic properties of phenolic acids, which are able to be accumulated in the brain at pharmacologically relevant levels, future studies should also identify which among the different metabolites produced as a consequence of phenolic acids' consumption may be responsible for the potential neuroprotective effects of this subgroup of polyphenols.

Keywords: polyphenols; cognitive status; Alzheimer disease; neurodegeneration; neuroprotection; secondary prevention

\section{Introduction}

Growing evidence supports the hypothesis that dietary factors may play a role in healthy aging, including a protective effect against age-related cognitive decline [1]. A recent summary of the literature showed that dietary polyphenols have been associated with better cognitive status and their supplementation may prevent cognitive decline [2]. 
The most common group of polyphenolic compounds is represented by flavonoids and the main subclasses flavonols, flavones, flavanones, flavan-3-ols, anthocyanidins, and isoflavones, largely contained in fruits and vegetables [3]. The potential of these molecules in preventing and/or counteracting neurodegenerative phenomena has been recently considered [4-6]. Other classes of polyphenols largely investigated for their potential role in neurodegenerative diseases include stilbenes (such as resveratrol, contained in red wine), tyrosol (such as oleuropein, contained in olive oil), and curcuminoid (such as curcumin, contained in turmeric) [2]. Finally, another non-flavonoid group of polyphenols includes phenolic acids, a heterogeneous family of polyphenols commonly consumed, largely underrated, and far less investigated concerning their potential effects against neurodegenerative diseases [2]. From a general point of view, phenolic acids may exert a number of neuroprotective and cognition-enhancing effects related to the anti-amyloidogenic and anti-aggregant activity of these natural compounds [2]. Moreover, phenolic acids have been demonstrated to inhibit the aggregation of proteins involved in the pathogenesis of various neurodegenerative pathologies characterized by cognitive deterioration, including Alzheimer's disease (AD), Parkinson's disease (PD), dementia with Lewy bodies, and multiple system atrophy [7-9]. Thus, there is a growing body of literature on preclinical studies and experimental models showing a mechanistic rationale for the application of polyphenols against cognitive impairment, with possible use in the future toward more advanced and disabling dementias, including AD.

Recently, neuroprotective [10] and cognition-improving [11,12] effects of this class of natural compounds have been reviewed. However, there is currently no updated summary providing an overview of the studies focused on cognitive outcomes. The aim of this study is to review current evidence from human studies on phenolic acid intake and cognitive status, including cognitive impairment and dementias, as well as provide an overview of preclinical mechanistic studies on these compounds on neurodegeneration and other mechanisms leading to cognitive disorders.

\section{Chemical Composition, Major Groups, and Dietary Sources of Phenolic Acids}

Phenolic acids (or phenolcarboxylic acids) are aromatic acid compounds containing a phenolic ring and an organic carboxylic acid function [3]. The main groups composing this class of polyphenols are hydroxycinnamic acids and hydroxybenzoic acids. Hydroxycinnamic acids are chemically characterized by a structure constituted of a nine carbon (C6-C3) skeleton and a side chain double bond characterized by a cis or trans configuration. Among the most studied molecules belonging to this group, caffeic, chlorogenic, o-coumaric, p-coumaric, m-coumaric, ferulic, and cinnamic acids are the most commonly consumed in the human diet being contained in coffee [13]. Hydroxybenzoic acids include in their structure a $\mathrm{C} 6-\mathrm{C} 1$ carbon backbone with methoxylations and hydroxylations at the aromatic ring: the main molecules of interest include gallic, p-hydroxybenzoic, vanillic, syringic, and protocatechuic acids; the main dietary sources of these compounds are certain cereals (i.e., bran, grain brown rice, and derivatives, such as beer), olive oil, tea (despite some differences between types and fermentation), some fruits (i.e., cherries, plums, and gooseberries among others), and red wine [13].

\section{Studies Conducted on Humans on Phenolic Acids and Cognitive Status}

Studies investigating the association between phenolic acid intake and cognitive outcomes are rather limited. The first published study was conducted on the SU.VI.MAX ("Supplémentation en Vitamines et Minéraux Antioxydants") study including 2574 middleaged adults (mean age 66 years old) participating in the cohort assessed in 1994-1996 for cognitive function with four neuropsychological tests (phonemic and semantic fluency, the RI-48 Cued Recall test, the Trail Making test, and Forward and Backward Digit Span) and followed up to 2007-2009; the authors reported that intake of hydroxybenzoic acids was positively associated with language and verbal memory (especially with episodic memory; $P=0.0004$ ) [14]. After being unexplored for several years, a recent study conducted on the 
SUN ("Seguimiento Universidad de Navarra") Project, a Spanish prospective cohort study from which a subsample of 806 older participants (mean age 66 years old) was investigated for cognitive function through the validated Spanish Telephone Interview for Cognitive Status-modified score, showed no association between phenolic acid intake and cognitive status [15]. Finally, a recent study conducted by our group supports a protective effect of phenolic acid intake against cognitive decline. The study involved 883 older individuals (mean age 64.9 years old, 56.7\% female) from the MEAL (Mediterranean healthy Eating, Aging, and Lifestyle) study recruited from the general population of Catania, South Italy, showed an inverse association between the highest quartile of total phenolic acid intake and impaired cognitive status [odds ratio $(\mathrm{OR})=0.36,95 \%$ confidence interval $(\mathrm{CI}): 0.14$ to 0.92] [16]. Among specific groups and individual compounds, significant associations were found for greater intake of hydroxycinnamic acids (OR $=0.35,95 \% \mathrm{CI}: 0.13$ to 0.91 ) and caffeic acid (OR $=0.32,95 \%$ CI: 0.11 to 0.93 ) [16].

As previously mentioned, the most common dietary sources of phenolic acids, on which some studies have been conducted concerning cognitive outcomes, include coffee, tea, red wine, and olive oil. A recent meta-analysis showed that moderate alcohol $(<11 \mathrm{~g} /$ day) and coffee ( $<2.8$ cups/day) intake was associated with a lower risk of cognitive deficits or only dementia [17]. Moreover, the same study reported an inverse linear association between green tea consumption and cognitive impairment (1 cup/day, relative risk $=0.94 ; 95 \%$ CI: 0.92 to 0.97 ) [17].

\section{Preclinical Studies on Phenolic Acids and Cognitive Disorders: Molecular Mechanisms and Neuroprotective Activity}

Phenolic acids can exert neuroprotective and pro-cognitive activities through numerous mechanisms that may differ across the various natural compounds part of this heterogeneous group (Figure 1).

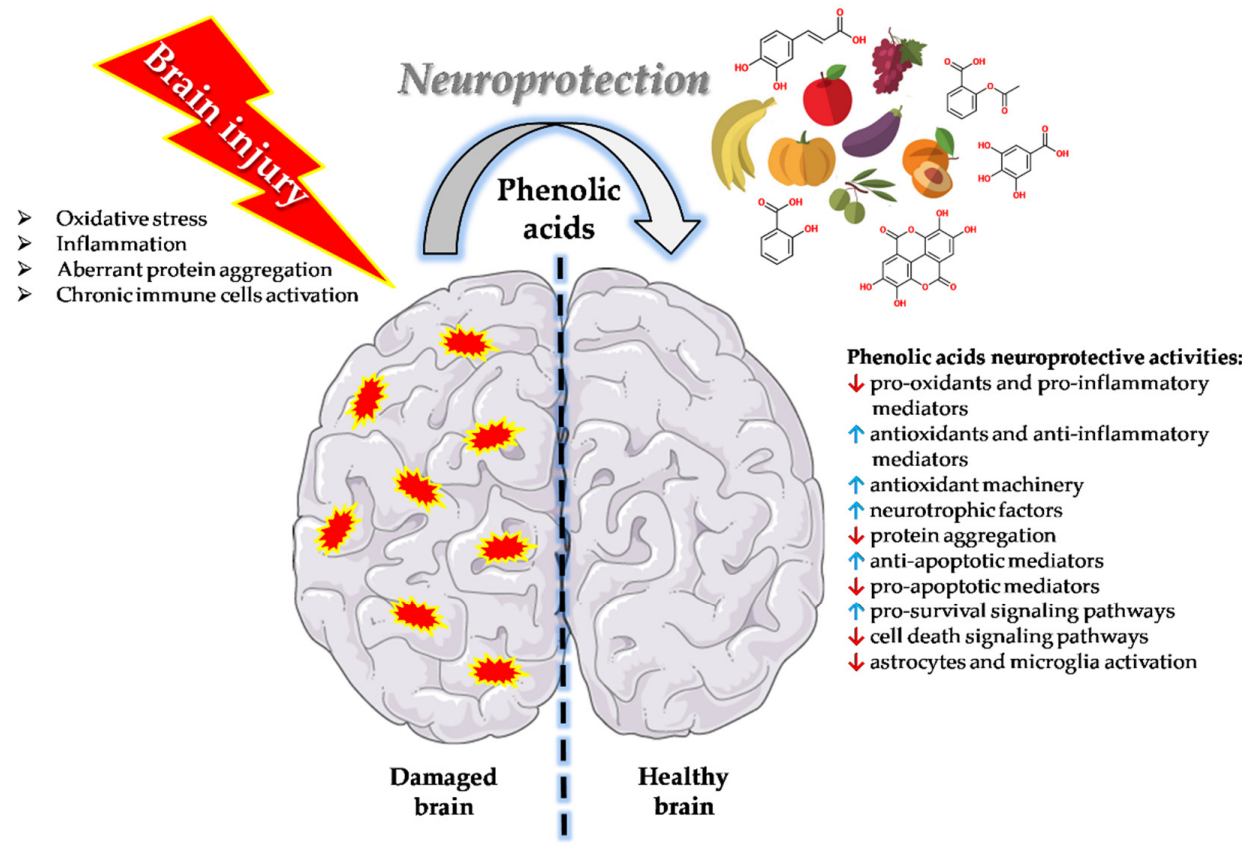

Figure 1. Phenolic acids neuroprotective activities. Phenolic acids can exert neuroprotection through numerous mechanisms including the ability to decrease the levels of pro-oxidants and pro-inflammatory mediators, increase the production and/or the activity of antioxidants and antiinflammatory mediators, enhance the antioxidant machinery, rescue and/or increase the release of neurotrophic factors, prevent and/or counteract protein aggregation, increase the expression of anti-apoptotic mediators and down-regulate that of pro-apoptotic mediators, activate pro-survival signaling pathways also blocking cell death signaling pathways, and decrease the activity of reactive astrocytes and microglia. 


\subsection{Caffeic Acid and Caffeic Acid Phenethyl Ester}

Recent evidence suggests that caffeic acid exerts neuroprotective effects through modulating neuroinflammation and oxidative stress. In particular, caffeic acid has been shown to attenuate lipopolysaccharide (LPS)-induced sickness behaviour and neuroinflammation in mice [18]. This phenolic acid, administered orally $(30 \mathrm{mg} / \mathrm{kg})$ one hour prior to LPS $(1.5 \mathrm{mg} / \mathrm{kg})$, reduced in a dose-dependent manner the levels of the inflammation marker tumor necrosis factor-alpha (TNF- $\alpha$ ) in the serum. Additionally, caffeic acid administration rescued the antioxidant defence system via a significant decrease of malondialdehyde (MDA; one of the final products of polyunsaturated fatty acids peroxidation in the cells [19]) and rescue of glutathione (GSH; a major tissue antioxidant [20]) levels in the brain. Although the pathophysiology of PD is not yet clearly understood, the evidence suggests its multifactorial nature. An aberrant aggregation of a neuronal protein, namely $\alpha$-synuclein ( $\alpha$-syn), has been recognized among key contributors to the process of neurodegeneration and PD pathophysiology. Interestingly, an inhibitory effect of caffeic acid against an antidepressant-induced fibrillogenesis of human $\alpha$-syn in a concentration-dependent manner was proved [21], suggesting the design of new therapeutic drugs for PD based on caffeic acid structure. In an in vivo study employing an epilepsy mouse model, caffeic acid showed neuroprotective action against oxidative and DNA damage [22]. In a different in vivo study, caffeic acid at two different doses (4 or $8 \mathrm{mg} / \mathrm{kg}$ ) was able to reduce the latency to sleep in the diazepam-induced sleeping time test as well the genotoxic damage induced by aspilocarpine in an acute seizure model of mouse [23]. Chang et al. demonstrated the protective effect of caffeic acid against $\mathrm{AD}$ through the modulation of cerebral insulin signaling, amyloid- $\beta(A \beta)$ accumulation, and synaptic plasticity in a hyperinsulinemic rat model [24]; in particular, the oral administration of caffeic acid $(30 \mathrm{mg} / \mathrm{kg})$ significantly ameliorated memory and learning impairments, enhanced superoxide dismutase (SOD) and glutathione free radical scavenger activity, increased the levels of p-glycogen synthase kinase- 3 beta (GSK-3 $\beta$ )(Ser9) and decreased the expression of p-tau protein in the hippocampus, attenuated the expression of amyloid precursor protein (APP) and $\beta$-site APP cleaving enzyme, and increased the expression of synaptic proteins in this rat model.

Caffeic acid phenethyl ester has shown to be neuroprotective in rats exposed to ionizing radiation by decreasing radiation-induced oxidative damage through the amelioration of SOD activity and the decrease in MDA levels in the brain [25]. This ester of caffeic acid has also been shown to exert neuroprotection through the modulation of different pathways such as nuclear factor erythroid 2-related factor 2 (Nrf2), nuclear factor kappalight-chain-enhancer of activated B cells (NF- $\mathrm{kB}$ ), and signal transducer and activator of transcription 3 (STAT3) [26] along with 3-kinase/protein kinase B, Bax and BAD, Bcl-2 and $\mathrm{Bcl}-\mathrm{XL}$, and mitogen-activated protein kinase (MAPK) [27]. The protective effects of caffeic acid phenethyl ester, injected intraperitoneally (i.p.), against ifosfamide (IFOS)induced central neurotoxicity in rats was mediated by its ability to decrease MDA and protein carbonyl levels at brain level [28,29]. In vitro, caffeic acid phenethyl ester protected PC12 cells from 1-methyl-4-phenylpyridinium (MPP+)-induced cell death by increasing the network of neurites as well as the expression of proteins responsible for axonal growth (GAP-43) and synaptogenesis (synaptophysin and synapsin I) [30]. Caffeic acid phenethyl ester also possesses antioxidant activity, as demonstrated in a work carried out by Tsai et al. in which it significantly inhibited the expressions of inducible nitric oxide synthase (iNOS), cyclooxygenase (COX)-2, and the production of nitric oxide (NO) in LPS-activated microglial cells [27]; these effects were paralleled by the attenuation of LPS-dependent MAPK and Akt signaling pathways and the induction of heme oxygenase- 1 (HO-1) and erythropoietin (EPO). Lastly, caffeic acid phenethyl $(30 \mathrm{mg} / \mathrm{kg})$ has shown to be neuroprotective by counteracting 3-nitropropionic acid-induced striatal neurotoxicity, representing a model of Huntington's disease (HD) [31]; it reduced striatal damage and the behavioral deficits also reducing the activation of astrocyte (glial fibrillary acidic protein; GFAP) and microglia (CD45). 


\subsection{Chlorogenic Acid}

Chlorogenic acid has been demonstrated to protect primary neurons against glutamate neurotoxicity by regulating the intracellular concentrations of $\mathrm{Ca}(2+)$ [32]. This polyphenol has also shown its neuroprotective and anti-inflammatory potential in microglial cells infected with herpes simplex virus [33]; in these infected cells, chlorogenic acid increased the survival rate, prevented the increase in toll-like receptor 2 (TLR2), TLR9, and Myd88, attenuated TNF- $\alpha$ and interleukin (IL)- 6 release, and reduced the expression of NF- $\mathrm{KB}$ p65. Chlorogenic acid-enriched extract from Eucommia ulmoides showed an antidepressant potential in vivo paralleled by neuroprotection and promotion of serotonin release through the enhancement of synapsin I expression in vitro [34]. Chlorogenic acid also possesses antioxidant activity; in fact, it was able to decrease MDA and reactive oxygen species (ROS) levels in hydrogen peroxide $\left(\mathrm{H}_{2} \mathrm{O}_{2}\right)$-induced alterations in rat brain slices [35]. In a different study, the expression pattern of N-methyl-D-aspartate (NMDA) receptors revealed an antiepileptic potential of chlorogenic acid in a pilocarpine-induced epileptic mouse model [36]. The administration of chlorogenic acid ( $5 \mathrm{mg} / \mathrm{kg}$ ) reduced seizures through the reduction of lipid peroxidation and nitrite content, as well as the mRNA expressions of NMDA receptors, metabotropic glutamate receptor 1 (mGluR1) and mGluR5 in the hippocampus. The beneficial effects of chlorogenic acid were also observed in the case of PC12 cells challenged with ethanol [37]. In this experimental model, the polyphenol increased the cell viability, promoted the proliferation of damaged cells, increased the distribution ratio of the cells at the G2/M and S phases, enhanced mitochondrial transmembrane potential, up-regulated the expression of Bcl-2 and GAP-43, and down-regulated the expression of caspase-3. A study carried out by Taram et al. investigated the neuroprotective effects of chlorogenic acid and its major metabolites in primary cultures of rat cerebellar granule neurons [38]. Chlorogenic and caffeic acids displayed a relevant neuroprotective effect against the NO donor, sodium nitroprusside, while caffeic acid and ferulic acid significantly protected neurons against glutamate-induced cell death. It is worth highlighting that caffeic acid was the only compound to display significant protection against $\mathrm{H}_{2} \mathrm{O}_{2}$ stimulation, inhibition of proteasome, caspase-dependent intrinsic apoptosis, and endoplasmic reticulum stress.

\subsection{Ferulic Acid}

The neuroprotective activity of ferulic acid often depends on the combination of its antioxidant and anti-inflammatory properties. Ferulic acid was able to increase serotonin and norepinephrine levels, but not those of dopamine, in the mouse hippocampus and frontal cortex, brain regions that play a key role in the pathophysiology of mood disorders [39]. It also reduced depressive-like behavior measured as tail suspension and forced swim tests (TST and FST); the inhibition of monoamine oxidase A (MAO-A) activity coming from ferulic acid treatment was also demonstrated in this study. The antioxidant defense system plays a pivotal role in the antidepressant-like effect exerted by ferulic acid. In fact, improvement of TST and FST scores has been paralleled by the increased expression of SOD, catalase (CAT), and glutathione peroxidase (GPx) in the cerebral cortex of mice [40]. SOD and CAT were also positively modulated in a rotenone (ROT)-induced rat model of PD [41], in which ferulic acid was also able to rescue dopaminergic neurons in substantia nigra pars compacta area and nerve terminals in the striatum, restore glutamate levels, prevent lipid oxidation, reduce the levels of ionized calcium-binding adapter molecule (Iba-1), GFAP, pro-inflammatory cytokines, COX-2, and iNOS. A combination of antioxidant and anti-inflammatory activities of ferulic acid was also observed in microglial cells stimulated with LPS (inhibition of TNF- $\alpha$, IL-6, IL-1, and NO; reduction of COX-2 and iNOS) [42] and Neuro-2a cells challenged with $\mathrm{H}_{2} \mathrm{O}_{2}$ (up-regulation of brain-derived neurotrophic factor (BDNF) gene and down-regulation of nNOS, eNOS, COX-2, IL-1 $\beta$, caspase-9, and BCL-2 genes) [43]. A significant up-regulation of the BDNF, postsynaptic density protein (PSD95), and synapsin I levels was also observed in the prefrontal cortex and hippocampus of a chronic model of depression (i.e., chronic unpredictable mild stress) [44]. PC12 cells are 
often used as a cell model to study the neuroprotective features of candidate molecules. In this cell line, ferulic acid dose-dependently inhibited the LPS-induced production of TNF- $\alpha$ and IL- $1 \beta$ and attenuated the LPS-induced up-regulation of phosphodiesterase 4 (PDE4) activity; furthermore, ferulic acid decreased the up-regulation of the PDE4B mRNA and reversed the down-regulation of CAMP-response element binding protein (CREB) and pCREB induced by LPS [45]. The modulation of the MAPK kinase (MEK)/ extracellular signal-regulated kinases (ERK)/p90 ribosomal S6 kinases (p90RSK) signaling pathway, and the related neuroprotective activity, was observed instead in an in vivo model of focal cerebral ischemic injury [46]. With regard to its anti-apoptotic activity, increased cell viability, prevented membrane damage, scavenged free radicals, increased the activity of $\mathrm{SOD}$, decreased intracellular free $\mathrm{Ca}(2+)$ levels, lipid peroxidation, and prostaglandin E2 (PGE2) production in hypoxia-stressed PC12 cells. Ferulic acid also reduced p-p38 MAPK, caspase-3, and COX-2 activation [47].

\subsection{Gallic Acid}

Gallic acid is a phenolic acid that may be effective against age-related and diseaserelated cognitive decline, because of its well-documented antioxidant, anti-inflammatory, and neuroprotective activities. From a mechanistic perspective, gallic acid has been reported to decrease the level of cytokines in microglia cells and protect neurons from $A \beta$-induced neurotoxicity by inhibiting NF- $\mathrm{kB}$ acetyltransferase [48]. Interestingly, in the same study, it was also observed that gallic acid counteracted $\mathrm{A} \beta$-induced cognitive dysfunction in mice [48]. In line with these findings, another preclinical study reports that administration of gallic acid prevented memory deficits and synaptic impairment by suppressing the release of the pro-inflammatory cytokines IL-1 $\beta$, IL-6, and TNF- $\alpha$ [49]. Moreover, it was found that chronic administration of gallic acid rescued learning and memory deficits of A $\beta$-protein precursor/presenilin 1 (APP/PS1) transgenic mice, an animal model of $\mathrm{AD}$ [50]. In particular, this beneficial effect was linked to reduced neuroinflammation in terms of reduced $A \beta$ plaque-associated microgliosis and astrocytosis [50]. In this study, the authors further show that gallic acid is able to behave as a dual $\alpha / \beta$-secretase modulator, consequently affecting APP processing, and that can promote APP cleavage by $\alpha$-secretase through increasing the activity of the disintegrin and metalloproteinase domain-containing protein 10 (ADAM10). This leads to an accumulation of soluble APP- $\alpha$ protein, which has been found to have neurotrophic and neuroprotective activities [51] and to enhance synaptic plasticity [52]. Similarly, the pro-cognitive effect of gallic acid as well as its beneficial effect on synaptic impairment were further observed and associated with a disrupting action of this small molecule on A $\beta 1-42$ aggregation [53]. Furthermore, it has been reported that tannic acid, a hydrolysable glycosidic polyphenol polymer of gallic acid, has neuroprotective, anti-inflammatory, and pro-cognitive properties. It indeed prevented streptozotocin (STZ)-induced memory impairment, and restored the increased level of the pro-inflammatory cytokines IL- 6 and TNF- $\alpha$ as well as the decreased level of Akt and pAkt [54]. Gallic acid also showed neuroprotective effects in a rat model of traumatic brain injury (TBI) ameliorating memory and long-term potentiation (LTP) impairment through the decrease in brain lipid peroxidation (MDA) and pro-inflammatory cytokines (IL- $1 \beta$, IL-6, and TNF- $\alpha$ ) in the brain.

The neuroprotective effects of gallic acid against STZ-induced oxidative damage in rat striatum have been demonstrated [55]. In this animal model, the oxidative damage was counteracted by the chronic administration of gallic acid ( $30 \mathrm{mg} / \mathrm{kg}$ for 26 days) that normalized thiobarbituric acid reactive substances (TBARS) and total thiol contents, as well as the activity of the antioxidant enzymes GPx, CAT, and SOD activities in the rat striatum. Still in the context of the antioxidant activity, gallic acid, orally administered at the dose of 60 and $120 \mathrm{mg} / \mathrm{kg}$, was able to ameliorate cyclophosphamide-induced neurotoxicity in Wistar rats through free radical scavenging activity and the rescue of normal levels of cerebellar and cerebral CAT, SOD, MDA, glutathione S-transferase (GST), GPx, and nitrite [56]. A very recent work investigated the effects of gallic acid against sodium arsenite-induced 
neurotoxicity in rats [57]. In this rat model, gallic acid significantly reversed sodium arsenite-induced reduction of step-through latency, latency to fall, and crossing, rearing, and grooming activity, being also able to reduce MDA and increase GSH levels and GPx activity in different regions of the brain. Lastly, nutritional supplementation of gallic acid $(100 \mathrm{mg} / \mathrm{kg})$ ameliorates AD-type hippocampal neurodegeneration and cognitive impairment (spatial memory and learning) induced by aluminum chloride $\left(\mathrm{AlCl}_{3}\right)$ exposure in adult Wistar rats [58]. In more detail, following $\mathrm{AlCl}_{3}$ exposure there was a significant decrease in CAT, GSH, and SOD, as well as serum electrolyte and neurotransmitter levels with a corresponding increase in MDA, hydrogen peroxide $\left(\mathrm{H}_{2} \mathrm{O}_{2}\right)$, and $\mathrm{NO}$ that was restored nearly to normal after gallic acid administration.

\subsection{Rosmarinic Acid}

The ability of rosmarinic acid $(4 \mathrm{mg} / \mathrm{kg})$ to reduce the levels of free radicals and DNA damage in the kindling CF-1 mouse model of epilepsy pentylenetetrazole (PTZ)-induced has been demonstrated [22]. This molecule was also shown to increase the latency and decrease the percentage of seizure incidents in the same mouse model. In a different study employing the same animal model, the same dosage of rosmarinic acid coupled to diazepam improved the latency to first seizures, also reducing the latency to sleep in the diazepam-induced sleeping time test. The same study also reported the ability of rosmarinic acid (2 or $4 \mathrm{mg} / \mathrm{kg}$ ) to decrease pilocarpine-induced genotoxic damage in a mice acute seizure model [23]. The neuroprotective activity exerted by rosmarinic acid could also depend on its modulatory activity on the Nrf2 pathway. In fact, as shown by Fetoni et al., the i.p. administration of rosmarinic acid $(10 \mathrm{mg} / \mathrm{kg})$ in male adult Wistar rats attenuated noise-induced hearing loss and hair cell damage, reduced the ROS imbalance induced by noise as well as superoxide generation and lipid peroxidation, and induced HO-1 up-regulation through the activation of Nrf2-antioxidant-responsive element (ARE) [59]. In a study employing $\mathrm{C} 6$ glial cells, rosmarinic acid was able to increase cell viability by decreasing both oxidative stress and lipid peroxidation $\mathrm{H}_{2} \mathrm{O}_{2}$ induced [60]. In the same $\mathrm{H}_{2} \mathrm{O}_{2}$-stimulated cells, rosmarinic acid was able to reduce the gene and protein expression levels of iNOS and COX-2. The antioxidant power of rosmarinic acid, characterized by the reduction in the levels of ROS and reactive nitrogen species (RNS), the inhibition of lipid peroxidation, along with the inhibition of monoamine oxidases (MAO-A and MAO-B) and catechol-O-methyltransferase (COMT) enzymes, has also been demonstrated [61]. Of note, no cytotoxicity was observed on polymorphonuclear rat cells, even if used at a concentration higher than those displaying the antioxidant profile and enzyme inhibition effects. Spinal cord injury (SCI) has been linked to loss of neuronal function. In rats with SCI, the i.p. administration of rosmarinic acid $(10 \mathrm{mg} / \mathrm{kg})$ significantly enhanced the antioxidant status, decreased oxidative stress, and down-regulated NF- $\mathrm{kB}$ and pro-inflammatory cytokines [62]. Stress represents a risk factor of $\mathrm{AD}$, and it has been shown that stress could induce tau phosphorylation and increase tau insolubility in the brain. In a chronic restraint stress mouse model, rosmarinic acid was able to counteract the stress-induced tauopathy by decreasing $\mathrm{p}$-tau and insoluble p-tau formation and reverting the abnormal changes of chaperones and peptidyl-prolyl cis/trans isomerase (Pin1) [63]. As shown by Hwand et al., the acute rosmarinic acid treatment enhances LTP, $\mathrm{BDNF}$, and AMPA glutamate receptor 2 (GluR-2) protein expression, and cell survival rate against scopolamine challenge in rat organotypic hippocampal slice cultures [64]. Lastly, rosmarinic acid exerted neuroprotection in a neuropathic pain animal model by decreasing the levels of different spinal pro-inflammatory markers such as COX2, PGE2, IL-1 $\beta$, matrix metallopeptidase 2 (MMP2), and NO [65].

\subsection{Acetylsalicylic Acid}

Acetylsalicylic acid is a frequently used drug for the treatment of inflammatory pain and fever. The neuroprotective activity of acetylsalicylic acid $(50 \mathrm{mg} / \mathrm{kg})$ has been shown in rats challenged with 2,3,7,8-tetrachlorodibenzo-p-dioxin, as demonstrated by the exami- 
nation of histopathological and ultrastructural images of hippocampus areas characterized by decreased neurodegeneration and smaller inflammatory reactivity [66]. In particular, acetylsalicylic acid was able to decrease the degenerative changes, inflammatory reactivity, as well as the expression of estrogen receptors (atrophy). Older human immunodeficiency virus (HIV)-1 transgenic rats represent a model for HIV-1-associated neurocognitive disorders. In these rats, the chronic low-dose acetylsalicylic acid reduced brain arachidonic acid-metabolite markers of neuroinflammation and oxidative stress (15-epi-lipoxin A4 and 8-isoprostane, PGE2 and leukotriene B4) [67]. In a recent study carried out by Yi et al., the administration of acetylsalicylic acid in combination with statin lowered neurological deterioration as well as platelet aggregation and platelet-leukocyte aggregate numbers in patients after acute ischemic stroke [68]. In a different in vivo study, acetylsalicylic acid (30 mg/kg i.p.) significantly improved learning and memory measured by Morris water maze in ischemic animals (transient middle cerebral artery occlusion (MCAO)) [69]. Moreover, infarction volume and neural changes were significantly counteracted by salicylic acid administration. The normalization of brain function has also been attributed to the treatment with acetylsalicylic acid; this phenolic compound enhanced the inhibition of the allostimulatory capacity of dendritic cells mediated by rapamycin, also reducing the number of mouse bone marrow-derived immature dendritic cells expressing CD40 protein and major histocompatibility complex class II (MHC II) molecules after LPS stimulation [70]. Acetylsalicylic acid has also shown the ability to modulate microglia (BV-2 cells) activity [71]. In these cells, acetylsalicylic acid decreased the expression of transferrin receptor 1 (TfR1), while it up-regulated ferroportin 1 (Fpn1) and ferritin expressions. The authors also demonstrated a higher expression of TfR1 and Fpn1, while ferritin contents, IL-6, TNF- $\alpha$, and hepcidin mRNA levels were lower in cells treated with acetylsalicylic acid plus LPS compared to cells stimulated with LPS only.

\subsection{Tannic Acid}

Tannic acid is a polyphenol that has shown a highly efficient metal chelating activity. Tannic acid administration to male Wistar-albino rats (50 mg/kg/day for 16 weeks) was able to elevate the concentrations of NR2A and NR2B, two subunits of NMDA receptors, also increasing the activity of antioxidant enzymes such as GPx and decreasing lipid peroxidation measured through MDA at hippocampal level [72]. Tannic acid, administered at the same dosage, also alleviated lead acetate-induced neurochemical perturbations in rat brain [73]. Neuroprotective efficacy of tannic acid on lead acetate-treated rats was exerted through the restoration of the antioxidant status (GSH levels) and antioxidant enzymes' activity (GST, glutathione reductase (GR), GPx, and SOD), the reduction of oxidative stress (TBARS), and the decrease in neurotoxicity biomarkers enzymes (acetylcholinesterase (AChE), MAO, and $\mathrm{Na}^{+} / \mathrm{K}^{+}$ATPase). The therapeutic potential of tannic acid has also been validated in an animal model of ischemia/reperfusion injury [74]. Tannic acid significantly reduced oxidative stress, as indicated by the decreased levels of ROS and MDA, whereas increased SOD and nuclear respiratory factor-1 (NRF-1) levels in brain tissues of rats with brain ischemia. The ability of tannic acid to positively modulate behavioral deficits and neurodegeneration has been shown in a rat model of MCAO [75]. MCAO animals pretreated with tannic acid showed a marked reduction in infarct size, improved neurological function, and suppressed neuronal loss with a down-regulation of GFAP expression. The depletion of the activity of antioxidant enzymes (GPx, GR, GST, glucose-6-phosphate dehydrogenase, SOD, and CAT) and the content of GSH in the MCAO group were protected significantly in the MCAO group pretreated with tannic acid, while the levels of TBARS and pro-inflammatory cytokines were decreased.

\subsection{Protocatechuic Acid}

Protocatechuic acid is a dihydroxybenzoic acid, representing a major metabolite of antioxidant polyphenols found in green tea. Different studies have shown the ability of this phenolic acid to protect PC12 cells against different insults. Protocatechuic acid protected 
PC12 cells against the toxicity (apoptosis) induced by $\mathrm{H}_{2} \mathrm{O}_{2}$, also increasing GSH levels and CAT activity [76]; in a different study, this phenolic acid suppressed MPP+-induced mitochondrial dysfunction and apoptotic cell death through the counteraction of the loss of mitochondrial membrane potential, formation of ROS, GSH depletion, activation of caspase-3, and down-regulation of Bcl-2 [77]. Protocatechuic acid exerted similar neuroprotective activity in PC12 cells challenged with ROT [78]. As shown by Zhang et al., the neuroprotective activity of protocatechuic acid has also been demonstrated in vivo; in fact, this phenolic acid, in combination with chrysin, prevented neuronal loss in both zebrafish and mice treated by 6-hydroxydopamine (6-OHDA) [79]. In the same study, the combination of protocatechuic acid and chrysin increased cell viability, up-regulated the expression of Nrf2 and of antioxidant enzymes (HO-1, SOD, CAT), decreased oxidative stress (MDA and iNOS), and inflammation (NF-KB) in 6-OHDA-treated PC12 cells. Protocatechuic acid was also able to modulate NF- $\mathrm{kB}$ along with MAPK signaling pathways, decreasing pro-inflammatory markers (TNF- $\alpha$, IL-6, IL-1 $\beta$, and PGE2), in LPS-treated BV2 microglial cells [80]. The administration (50 and $100 \mathrm{mg} / \mathrm{kg}$ ) of protocatechuic acid exerted glycemic control, attenuated brain mitochondrial dysfunction, and contributed to the prevention of brain oxidative stress in STZ-induced diabetic rats [81]. Protocatechuic acid protected cerebellar granule neurons from oxidative stress induced by $\mathrm{H}_{2} \mathrm{O}_{2}$ and from nitrosative stress induced by sodium nitroprusside [82]. Neuroprotective effects of protocatechuic acid orally administered $(100 \mathrm{mg} / \mathrm{kg})$ in mice treated with sodium arsenate $(5 \mathrm{mg} / \mathrm{kg})$ have also been shown [83]. Protocatechuic acid pre-treatment $(4 \mathrm{~h})$ before arsenic administration resulted in a decrease in oxidative stress and inflammation with lower levels of lipid peroxidation, iNOS, and NO. The pre-treatment also attenuated arsenic-associated histopathological changes observed at brain level. In a cell-free study, protocatechuic acid was demonstrated to inhibit the aggregation of $A \beta$ and $\alpha$-Syn, also destabilizing their preformed fibrils [84], then preventing PC12 cell death induced by A $\beta$ and $\alpha$-Syn.

\section{9. p-Coumaric Acid}

Coumaric acid is a molecule part of the polyphenol group widely found in plant-based foods [85]. This phenolic compound has been shown to possess neuroprotective activity both in vitro and in vivo. A study carried out by Guven et al. demonstrated that coumaric acid treatment after ischemia/reperfusion in rat sciatic nerves (SNI) reduced oxidative stress and axonal degeneration [86]. In particular, a significant decrease in MDA paralleled by increased levels of NRF-1 and SOD activity were observed in SNI animals receiving coumaric acid (i.p. single-dose, $100 \mathrm{mg} / \mathrm{kg}$ body weight (b.w.)) compared to SNI animals. Additionally, a significantly reduced ischemic fiber degeneration as well as $\mathrm{A} \beta$ protein accumulation were observed in rats treated with coumaric acid. Immunohistochemical staining analysis also demonstrated a significant decrease in hypoxia-inducible factor 1alpha (HIF1 $\alpha$ ) and NF-kB immunopositive neurons in spinal cord ischemia/reperfusion injury in rats treated with coumaric acid compared with ischemic animals [87]. Neuroprotective effects of the same dosage of p-coumaric acid have also been observed in a rat model of embolic cerebral ischemia [88]. The ability of p-coumaric acid to decrease oxidative damage, focal ischemia, and neurological deficit scores in the brain of rats characterized by cerebral ischemia is attributable to its antioxidant (decreased MDA) and anti-apoptotic (decreased caspase-3) activity. A recent study by Sakamula and Thong-Asa showed that the pre-treatment of animals with p-coumaric acid $(100 \mathrm{mg} / \mathrm{kg}$ for 2 weeks before inducing the injury) prevented ischemia reperfusion-induced brain oxidative stress (decreased MDA, increased activity of CAT and SOD), infarction size, and hippocampal neuronal death in cerebral ischemia reperfusion injuries [89]. A very recent paper demonstrated that p-coumaric acid mitigates LPS-induced brain damage by decreasing oxidative stress (MDA levels), increasing SOD and GSH levels, and decreasing AChE activity in the brains of mice. This phenolic acid also lowered the production of TNF- $\alpha$ and IL- 6 and suppressed neuronal apoptosis by decreasing caspase-3 and c-Jun levels [90]. Neuroprotective effects of p-coumaric acid were also observed in SH-SY5Y cells and primary rat cortical neurons 
challenged with corticosterone [91]. In these cells, p-coumaric acid effects are attributable to increased SOD and CAT activity as well as to increased CREB phosphorylation mediated by ERK1/2, Akt, and mammalian target of rapamycin (mTOR) pathways.

\subsection{Sinapic Acid}

Sinapic acid, also known as sinapinic acid, is a small naturally occurring hydroxycinnamic acid that can be found in different herbal materials such as berries, oil seeds, and cereals [92]. Sinapic acid has been shown to exert a neuroprotective activity in different animal models of neurodegenerative disorders such as AD and PD. When sinapic acid $(10 \mathrm{mg} / \mathrm{kg} /$ day, p.o.) was used in a mouse model of AD obtained by bilateral injection of $\mathrm{A} \beta$ into the hippocampus, it was able to rescue neuronal cell death at the CA1 region level and attenuate iNOS and nitrotyrosine expression as well as glial cell activation [93]. In the same study, sinapic acid administration, taking place for 1 week beginning immediately after $A \beta$ injection, significantly attenuated memory impairment. A different study was conducted to evaluate whether sinapic acid could exert a beneficial role in an experimental model of early PD represented by unilateral intrastriatal 6-OHDA-lesioned rat [94]. The administration of sinapic acid at the dose of $20 \mathrm{mg} / \mathrm{kg}$ b.w. improved turning behavior, counteracted the loss of dopaminergic neurons at substantia nigra pars compacta level, lowered iron reactivity, and attenuated oxidative stress measured as MDA and nitrite levels in midbrain homogenate. Since sinapic acid has shown both a $\gamma$-aminobutyric acid type A $(\mathrm{GABA}(\mathrm{A}))$ receptor agonistic property and free radical scavenging activity, its potential neuroprotective effects were examined in a global cerebral ischemia animal model (four vessel occlusion model-induced ischemia) [95]. Sinapic acid (10 mg/kg) administered i.p. to rats after induction of ischemia prevented neuronal damage and reduced memory impairment measured by Morris water maze test. The oral administration $(10 \mathrm{mg} / \mathrm{kg})$ of this acid was also able to prevent neuronal damage (CA1 and CA3 hippocampal regions) in mice challenged with kainic acid. This neuroprotective activity was accompanied by a reduction of reactive gliosis, iNOS expression, and nitrotyrosine formation in the hippocampus as well as by anticonvulsant and memory-enhancing effects [96].

\subsection{Ellagic Acid}

Ellagic acid is an organic heterotetracyclic phenolic compound obtained from grains and fruits, showing antioxidant activity and known to modulate several intracellular signaling pathways in humans [97]. In a study carried out by Jha et al., ellagic acid showed safety in vitro (SH-SY5Y cells) and neuroprotective activity in vivo (STZ-induced sporadic AD model). Oral administration of ellagic acid at the dose of $50 \mathrm{mg} / \mathrm{kg}$ for 30 days significantly reduced the STZ-induced biochemical aberrations, including oxidative stress (decreased MDA and increased GSH and CAT levels), pro-inflammatory markers (GFAP and $C$-reactive protein (CRP)), and AchE and $A \beta$ plaque levels. Ellagic acid also improved synaptic connectivity, as demonstrated by the elevated level of synaptophysin paralleled by an intact neural architecture. Lastly, the treatment with this phenolic compound normalized the behavioral abnormalities induced by STZ corresponding to irregular spontaneous alternation, reduced locomotor behavior, and memory decline. Beneficial effects of ellagic acid administration have also been observed in the case of animal models of scopolamine- and diazepam-induced cognitive impairments without altering the animals' locomotion [98]. Two different doses (30 and $100 \mathrm{mg} / \mathrm{kg}$ ) of ellagic acid were able to significantly revert the amnesia induced by scopolamine in the elevated plus maze and passive avoidance tests in mice, while the same doses antagonized the amnesia diazepam-induced in rats. Moreover, the chronic administration (10 consecutive days) of the lower dosage $(30 \mathrm{mg} / \mathrm{kg}$ ) of this heterotetracyclic phenolic compound ameliorated the memory in rats challenged with diazepam. In a research study carried out by Liu et al., ellagic acid improved endogenous neural stem cells proliferation and neurorestoration through the activation of the Wnt/ $\beta$ catenin signaling pathway both in vivo and in vitro [99]. Ellagic acid was administered intragastrically in a photothrombosis-induced rat model of brain injury for 7 consecutive 
days post-venous ischemia, improving nerve-related abilities and decreasing infarct volume and morphological changes at brain level, as well as enhancing the nestin content in the brain's semidarkness zone. The positive effects coming from the treatment for 2 days with ellagic acid were observed in an oxygen-glucose deprivation and re-perfusion (OGD/R) model of neural stem cells, in which the increased proliferation and expression of both $\beta$-catenin and Cyclin D1 at gene level were observed. As showed for sinapic acid, ellagic acid exerted neuroprotection in a PD animal model. In particular, ellagic acid $(50 \mathrm{mg} / \mathrm{kg}$ b.w./ $2 \mathrm{~mL}$, by gavages) restored the locomotion and reduced the levels of neuroinflammatory biomarkers (TNF- $\alpha$ and IL-1 $\beta$ ) in both the striatum and hippocampus of the rat model of PD obtained by injection of 6-OHDA (right medial forebrain bundle-lesioned rats) [100]. In a more recent publication, it has been shown how the oral administration of ellagic acid exerts neuroprotection against neonatal hypoxic brain injury through the inhibition of inflammatory mediators (e.g., NF-кB p65) and down-regulation of c-Jun N-terminal kinase (JNK)/p38 MAPK activation, also reducing infarct size, weight, and volume of the brain [101].

\subsection{Salicylic Acid}

Salicylic acid is a beta-hydroxy acid derivative of benzoic acid with anti-inflammatory, antibacterial, and neuroprotective activity that occurs as a natural compound in plants. In a methamphetamine (METH)-induced mouse model characterized by dopamine depletion, salicylic acid at both 50 and $100 \mathrm{mg} / \mathrm{kg}$ doses has shown the ability to scavenge ROS, revert mitochondrial dysfunction, ameliorate complex-I activity, and decrease neurotoxicity [102]. In this animal model, salicylic acid was also able to block METH-induced behavioral changes related to movement abnormalities. Paclitaxel and cisplatin are two well-known chemotherapeutic drugs often used in combination for the treatment of different solid tumors. Despite that, their use has been related to moderate or, in the worst scenario, severe neurotoxic effects. In primary cortex neurons obtained from Sprague-Dawley rat brains, salicylic acid counteracted the neurotoxicity induced by paclitaxel and cisplatin by exerting a marked antioxidant activity (increased total antioxidant capacity and decreased total oxidant status) [103].

\subsection{Homovanillic Acid}

Homovanillic acid, also known as 3-methoxy-4-hydroxyphenylacetic acid, is a monocarboxylic acid representing a major catecholamine metabolite produced by the action of MAO and COMT as a final product of dopamine metabolism [104]. In a 4-weeks, double-blind, randomized, placebo-controlled study involving a total of 47 subjects (22 men and 25 women), the increase in plasma homovanillic acid (>10\%) following cocoa extract $(1.4 \mathrm{~g} /$ day) consumption along with the improvement of the peripheral dopaminergic activity have been associated with the alleviation of depressive symptoms in overweight or obese adults [105]. In a different human study, the possible associations between changes regarding the levels of plasma homovanillic acid, the severity of psychotic symptoms as well as the improvement in psychotic subjects were investigated [106]. Plasma homovanillic acid levels were measured in patients with psychosis spectrum disorders before and after treatment with first- or second-generation antipsychotics for 6 weeks. Among the 58 subjects that fulfilled all inclusion criteria, 12 had first-episode psychosis (FEP). Data obtained in this study showed that changes in plasma homovanillic acid levels may have a predictive value for responsiveness and possible outcome in individual patients. With respect to FEP patients and patients with (chronic) relapsing psychoses, a significant difference in the decrease in plasma homovanillic acid was observed. This difference correlated with a symptomatic improvement and reaching remission status most pronounced in FEP patients. It was concluded that neuronal plasticity, expressed as changes in plasma homovanillic acid and reflecting the capacity to alter dopamine status, may be crucially involved in the individual responsiveness to antipsychotic treatment, especially in reaching the remission status. In a cohort study carried out by Neider et al., it was investigated 
the association between the levels of 5-hydroxyindoleacetic acid and homovanillic acid in cerebrospinal fluid (CSF), bullying during childhood, and later suicide in patients suffering from schizophrenia. It was observed that bullying during childhood and a low quotient of homovanillic acid/5-hydroxyindoleacetic acid in CSF are associated with later suicide [107]. With regard to in vitro studies on the neuroprotective activity of homovanillic acid, to the best of our knowledge, no findings are currently available.

\subsection{Syringic Acid}

Syringic acid is a naturally occurring phenolic compound and dimethoxybenzene that can be found in several plants including Ardisia elliptica and Schumannianthus dichotomus [108]. Different preclinical studies have shown the neuroprotective activity of this compound, especially against ischemic conditions. An in vivo study by Güven et al. demonstrated that syringic acid treatment $(10 \mathrm{mg} / \mathrm{kg}$ b.w., i.p.) in a cerebral ischemia model induced by artery occlusion reduced oxidative stress and neuronal degeneration by increasing the activity of SOD and the levels of NRF-1, while reducing MDA, caspase-3, and caspase-9 levels [109]. The neuroprotective effects of syringic acid were also investigated on spinal cord ischemia injury in rats. Syringic acid pretreatment $(10 \mathrm{mg} / \mathrm{kg}$ b.w., i.p.) exerted a significant neuroprotective activity characterized by the reduction of the number of apoptotic neurons along with reduced beclin-1 protein levels and caspase-3-immunopositive neurons [110]. Besides these, NRF-1 and SOD activity as well as neurological deficit scores were ameliorated by syringic acid pretreatment. The neuroprotective activity of syringic acid was also demonstrated in an in vitro model of cerebral ischemia established by subjecting hippocampal neurons to OGD/R [111], in which LDH leakage from cells, the expression of both Bax and caspase-3, as well as the intracellular levels of MDA, total ROS, and $\mathrm{Ca}(2+)$, were significantly reduced. The above-mentioned changes were paralleled by the increase in JNK phosphorylation, p38 phosphorylated expression, and cell viability, and the rescue of the intracellular SOD, mitochondrial membrane potential, and Bcl-2 expression. Very recently, it was published a study revealing the regulation of mitochondrial biogenesis and energy metabolism by syringic acid, beyond its antioxidant role in the diabetic rats' brain and spinal tissues [112]. In particular, Rashedinia et al. demonstrated that diabetic (STZ-induced) rats treated with syringic acid administered once per day $(100 \mathrm{mg} / \mathrm{kg})$ orally using an intragastric gavage for a period of 6 weeks, exhibited improved learning, memory, and movement deficiency; the administration of this phenolic compound also significantly up-regulated the brain mRNA expression of peroxisome proliferator-activated receptor gamma coactivator 1-alpha (PGC-1 $\alpha$ ) and NRF-1, both playing a crucial role in the regulation of energy metabolism, oxidative phosphorylation, and mitochondrial biogenesis. Lastly, syringic acid treatment increased the mtDNA/nDNA ratio in the brain as well as in the spinal cord of diabetic rats, also attenuating lipid peroxidation, inflammation, and demyelination in sciatic nerves. During the same year, Ogut et al. evaluated the effect of syringic acid ( $25 \mathrm{mg} / \mathrm{kg} /$ day, oral gavage) on dopamine expression by using behavioral tests related to short-term and recognition memory in Wistar rats [113]. Their results showed that syringic acid was able to increase dopamine along with the percent alternation, time spent in the novel arm, and frequency of novel arm entries of the rats after the Y-maze test. In addition to these effects, syringic acid ameliorated both discrimination index and exploration time in the novel object recognition (NOR) test, and increased the short-term and recognition memory in behavioral tests. A very recent paper showed the neuroprotective effects of syringic acid against $\mathrm{AlCl}_{3}$-induced oxidative stress-mediated neuroinflammation in a rat model of AD characterized by reduced memory and learning impairments [114]. The AD rats were supplemented with two doses of syringic acid (25 and $50 \mathrm{mg} / \mathrm{kg}$ ) for 30 days with an amelioration of the neurobehavioral impairments paralleled by the decreased expression of NF-kB, IL-1 $\beta$, IL-6, and TNF- $\alpha$. Syringic acid has also shown the ability to protect retinal ganglion cells against $\mathrm{H}_{2} \mathrm{O}_{2}$-induced apoptosis through the activation of phosphoinositide 3-kinase (PI3K)/ Akt signaling pathway [115]. 


\subsection{Cinnamic Aldehyde}

Cinnamic aldehyde, also referenced as cinnamaldehyde, is a phenylpropanoid organic compound synthesized by the shikimate pathway, occurring naturally as predominantly the trans isomer, that gives its distinctive flavor and odor to cinnamon [116]. The neuroprotective effects of cinnamic aldehyde have been reported in different neurodegenerative diseases, including PD. In an in vivo study employing a 1-methyl-4-phenyl-1,2,3,6tetrahydropyridine (MPTP) mouse model, the selective dopaminergic neuronal death at substantia nigra level was prevented by the administration of this phenylpropanoid compound (10 mg/kg/day, i.p., for 1 week after MPTP injection) [117]. Cinnamic aldehyde protected against MPTP-induced dopaminergic cell death and inhibited the autophagy (down-regulation of p62) stimulated in the substantia nigra of MPTP-treated mice. In the same study the authors, by performing in vitro experiments, were able to show that cinnamic aldehyde recovered MMP+-induced cell death in BE(2)-M17 Cells, also decreasing autophagy, confirming what was observed in vivo. In a different in vivo study, the potential therapeutic effects of cinnamic aldehyde on cerebral ischemia using a mouse model with permanent MCAO were investigated [118]. Mice were treated i.p. with three different doses $(25,50$, or $75 \mathrm{mg} / \mathrm{kg})$ of cinnamic aldehyde immediately after cerebral ischaemia, reducing neurological deficit scores, brain edema, and infarct volume; additionally, cinnamic aldehyde was able to inhibit the activation of TLR4, tumor necrosis factor receptor-associated factor 6 (TRAF6), and NF-kB, counteract the increased levels of TNF- $\alpha$, IL- $1 \beta, C-C$ motif chemokine ligand 2 (CCL2), and endothelial-leukocyte adhesion molecule-1, also reducing the infiltration of leukocytes into the ischaemic brain. Gürer et al. have recently demonstrated that this aldehyde can provide neuroprotection as well as attenuation of cerebral vasospasm after subarachnoid hemorrhage in rabbits [119]. The i.p. administration of cinnamic aldehyde ( $5 \mathrm{~min} ; 50 \mathrm{mg} / \mathrm{kg}$ / day), for a total of 3 days following an intracisternal blood injection, significantly increased the cross-sectional areas of the basilar artery, also decreasing both arterial wall thickness and hippocampal degeneration scores. In an in vitro study carried out by Emamghoreishi and collaborators the neuroprotective effects of cinnamic aldehyde against $A \beta$ inSH-SY5Y cells and the contribution of NMDA, ryanodine, adenosine receptors, and GSK-3 $\beta$ were investigated [120]. The results showed that the treatment with cinnamic aldehyde significantly reverted $A \beta$-induced toxicity, while adenosine, NMDA, and dantrolene (a ryanodine receptor antagonist) inhibited the neuroprotection exerted by this natural compound. Some of the concentrations of cinnamic aldehyde used were also able to suppress the $A \beta$-induced activation of GSK-3 $\beta$. METH represents an illegal drug able to markedly stimulate the central nervous system and induce degeneration of dopaminergic and serotonergic axons. The challenge of PC-12 cells with METH (2.5 mM) decreased the cell viability and GSH levels, increased ROS, and induced apoptosis [121]. Notably, the pre-treatment with trans-cinnamic aldehyde significantly attenuated all the alterations METH-induced. The combination of the trans form of this aldehyde with ellagic acid has also shown the potential to alleviate aging-induced cognitive impairment through the modulation of mitochondrial function (ROS, mitochondrial membrane potential, and ATP level) and inflammatory (TNF- $\alpha$ and IL-1 $\beta$ ) and pro-apoptotic (Bax and caspase-3) mediators in the prefrontal cortex of aged rats [122]. The therapeutic and neuroprotective potential of cinnamic aldehyde $(100 \mathrm{mg} / \mathrm{kg})$ has shown to decrease neutrophil recruitment, suppress ROS, reduce histologic damage and acute hippocampal dysfunction (Y-maze test) in a TBI rat model [123]. A study performed by Etaee et al. investigated the possible anxiolytic effects of the administration of cinnamic aldehyde (20 mg/ $\mathrm{kg} /$ day for 7 days) on male Swiss mice subjected to acute or chronic stress [124]. By using elevated plus maze and open field behavioral tests, the authors were able to demonstrate how cinnamic aldehyde could decrease anxiety-related behavior in mice.

Table 1 reports the names of each phenolic acid considered, their basic description, the effects on different disease models, and the possible mechanism of action as well as the chemical structure. 
Table 1. Phenolic acids and related characteristics.

\begin{tabular}{|c|c|c|c|c|c|}
\hline Phenolic Acids & Basic Description & Disease Models & Mode of Action & Ref. & Chemical Structure \\
\hline \multirow[t]{5}{*}{ Caffeic acid } & \multirow{5}{*}{$\begin{array}{l}\text { Organic compound classified as a } \\
\text { hydroxycinnamic acid. It consists } \\
\text { of both phenolic and acrylic } \\
\text { functional groups. Since it } \\
\text { represents an intermediate in the } \\
\text { biosynthesis of lignin (one of the } \\
\text { principal components of woody } \\
\text { plant biomass and its residues), } \\
\text { caffeic acid can be found in all } \\
\text { plants. }\end{array}$} & Mice treated with LPS & $\begin{array}{l}\text { - } \quad \text { Attenuated sickness behavior } \\
\text { - } \quad \text { Decreased oxidative stress } \\
\text { Decreased inflammation }\end{array}$ & [18] & \multirow{5}{*}{ ÒH } \\
\hline & & Human $\alpha$-syn aggregation & - Counteracted aggregation & [21] & \\
\hline & & Mouse model of epilepsy & $\begin{array}{l}\text { - Decreased oxidative stress and DNA } \\
\text { damage }\end{array}$ & [22] & \\
\hline & & $\begin{array}{l}\text { Mouse model of acute seizure } \\
\text { (diazepam and } \\
\text { aspilocarpine-induced) }\end{array}$ & $\begin{array}{l}\text { - } \quad \text { Reduced the latency to sleep } \\
\text { - } \quad \text { Reduced genotoxic damage }\end{array}$ & [23] & \\
\hline & & Rat model of hyperinsulinemia & 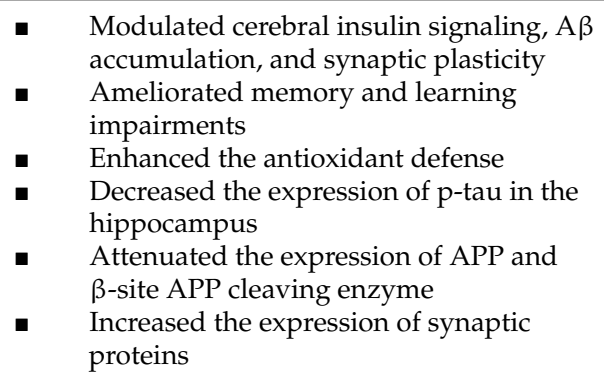 & [24] & \\
\hline
\end{tabular}


Table 1. Cont.

\begin{tabular}{|c|c|c|c|c|c|}
\hline Phenolic Acids & Basic Description & Disease Models & Mode of Action & Ref. & Chemical Structure \\
\hline \multirow[t]{6}{*}{ Caffeic acid phenethyl ester } & $\begin{array}{l}\text { Ester of caffeic acid and } \\
\text { phenethyl alcohol. }\end{array}$ & $\begin{array}{l}\text { Rats exposed to ionizing } \\
\text { radiation }\end{array}$ & $\begin{array}{l}\text { - Reduced oxidative stress } \\
\text { - } \quad \text { Ameliorated the antioxidant defense }\end{array}$ & [25] & \\
\hline & & Rats treated with IFOS & $\begin{array}{l}\text { - Decreased oxidative status and protein } \\
\text { carbonyl levels }\end{array}$ & {$[28,29]$} & \\
\hline & & $\begin{array}{l}\text { Mouse model of HD } \\
\text { (3-nitropropionic acid-induced) }\end{array}$ & $\begin{array}{l}\text { - Reduced striatal damage and the behavioral } \\
\text { deficits } \\
\text { - } \quad \begin{array}{l}\text { Reduced the activation of astrocyte and } \\
\text { microglia }\end{array}\end{array}$ & [31] & \\
\hline & & BV-2 cells treated with LPS & $\begin{array}{l}\text { - } \quad \text { Reduced oxidative stress } \\
\text { - } \quad \text { Attenuated LPS-dependent MAPK and Akt } \\
\text { signaling pathways } \\
\text { - } \quad \text { Attenuated induction of HO- } 1 \text { and EPO }\end{array}$ & [27] & \\
\hline & & PC12 cells treated with $(\mathrm{MPP}+)$ & $\begin{array}{l}\text { Increased the network of neuritis } \\
\text { Increased the expression of proteins } \\
\text { responsible for axonal growth and } \\
\text { synaptogenesis }\end{array}$ & [30] & \\
\hline & & $\begin{array}{l}\text { Rat cerebellar granule neurons } \\
\text { treated with SNP or } \\
\text { glutamate/glycine or } \mathrm{H}_{2} \mathrm{O}_{2}\end{array}$ & $\begin{array}{l}\text { - Decreased nitrosative stress, excitotoxicity, } \\
\text { and oxidative stress }\end{array}$ & [38] & \\
\hline
\end{tabular}


Table 1. Cont.

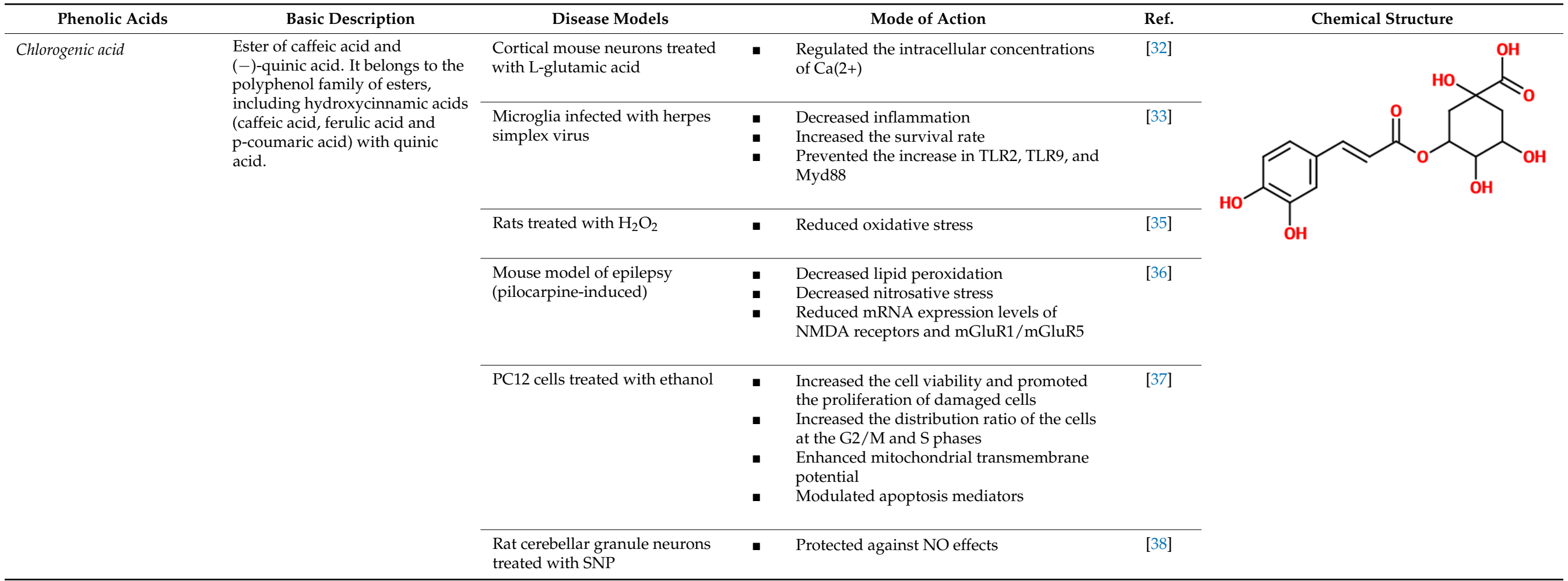


Table 1. Cont.

\begin{tabular}{|c|c|c|c|c|c|}
\hline Phenolic Acids & Basic Description & Disease Models & Mode of Action & Ref. & Chemical Structure \\
\hline \multirow[t]{9}{*}{ Ferulic acid } & \multirow[t]{9}{*}{$\begin{array}{l}\text { Natural phenylpropanoid found } \\
\text { in Euphorbia hylonoma herbs. It } \\
\text { is a substituted derivative of } \\
\text { trans-cinnamic acid. }\end{array}$} & N/A (untreated mice) & $\begin{array}{l}\text { - } \quad \text { Decreased inflammation } \\
\text { Decreased oxidative stress } \\
\text { - } \quad \text { Increased serotonin and norepinephrine levels } \\
\text { - } \quad \text { Inhibited depressive-like behavior } \\
\text { activity of MAO-A }\end{array}$ & [39] & \\
\hline & & N/A (untreated mice) & $\begin{array}{l}\text { Improved antidepressant-like effect } \\
\text { - Increased antioxidant machinery in the cerebral cortex of mice }\end{array}$ & [40] & \\
\hline & & Rat model of PD (ROT-induced) & $\begin{array}{l}\text { - Improved antidepressant-like effect } \\
\text { - Increased antioxidant machinery in the cerebral cortex of mice }\end{array}$ & [41] & \\
\hline & & Microglial cells treated with LPS & $\begin{array}{l}\text { - } \quad \text { Decreased inflammation } \\
\text { - } \quad \text { Decreased oxidative stress }\end{array}$ & [42] & \\
\hline & & Neuro-2a cells treated with $\mathrm{H}_{2} \mathrm{O}_{2}$ & $\begin{array}{l}\text { - Antioxidant and anti-inflammatory activity } \\
\text { - Up-regulated BDNF } \\
\text { - Modulated apoptosis mediators }\end{array}$ & [43] & \\
\hline & & $\begin{array}{l}\text { Mouse model of chronic } \\
\text { unpredictable mild stress }\end{array}$ & - Up-regulated BDNF, PSD95, and synapsin I levels & [44] & \\
\hline & & PC12 cells treated with LPS & $\begin{array}{l}\text { - } \quad \text { Decreased inflammation } \\
\text { - } \quad \text { Attenuated the up-regulation of phosphodiesterase } 4 \text { activity } \\
\text { - } \quad \text { Decreased the up-regulation of the PDE4B mRNA } \\
\text { Reverted the down-regulation of CREB and pCREB }\end{array}$ & [45] & \\
\hline & & $\begin{array}{l}\text { Rat model of focal cerebral } \\
\text { ischemic injury }\end{array}$ & - $\quad$ Down-regulated MEK/ERK/p90RSK signaling pathway & [46] & \\
\hline & & Hypoxia-stressed PC12 cells & $\begin{array}{l}\text { - Increased cell viability } \\
\text { - } \quad \text { Prevented membrane damage } \\
\text { - } \quad \text { Decreased oxidative stress } \\
\text { and PGE2 production } \\
\text { - } \quad \text { Reduced p-p38 MAPK } \\
\text { - Modulated apoptosis mediators }\end{array}$ & [47] & \\
\hline
\end{tabular}


Table 1. Cont.

\begin{tabular}{|c|c|c|c|c|c|}
\hline Phenolic Acids & Basic Description & Disease Models & Mode of Action & Ref. & Chemical Structure \\
\hline \multirow[t]{9}{*}{ Gallic acid } & \multirow[t]{9}{*}{$\begin{array}{l}\text { Phenolic acid classified as } \\
\text { trihydroxybenzoic acid. It is } \\
\text { found in gallnuts, sumac, witch } \\
\text { hazel, tea leaves, oak bark, and in } \\
\text { several other plants. }\end{array}$} & $\begin{array}{l}\text { Mice, Neuro-2A, and primary } \\
\text { microglial cells treated with } A \beta\end{array}$ & $\begin{array}{l}\text { Counteracted cognitive dysfunction and } \\
\text { down-regulated the levels of NF- } \mathrm{B} B \\
\text { acetylation in mice } \\
\text { - } \quad \text { Increased Neuro-2A cells viability } \\
\text { - Decreased inflammation in microglia }\end{array}$ & [48] & 0 \\
\hline & & Rat model of TBI & $\begin{array}{l}\text { - Prevented memory deficits and synaptic } \\
\text { impairment } \\
\text { - } \quad \text { Decreased inflammation }\end{array}$ & [49] & ОH \\
\hline & & $\begin{array}{l}\text { Transgenic mice model of AD } \\
\text { (APP/PS1) }\end{array}$ & - $\quad$ Rescued learning and memory deficits & [50] & \\
\hline & & $\begin{array}{l}\text { Transgenic mice model of AD } \\
\text { (APP/PS1) }\end{array}$ & $\begin{array}{l}\text { Improved cognition } \\
\text { - } \quad \text { Counteracted synaptic impairment } \\
\text { - } \quad \text { Reduced } A \beta \text { aggregation }\end{array}$ & [53] & \\
\hline & & Rat model of TBI & $\begin{array}{l}\text { - Improved memory and LTP impairment } \\
\text { - } \quad \text { Decreased lipid peroxidation } \\
\text { - Decreased inflammation }\end{array}$ & [54] & \\
\hline & & $\begin{array}{l}\text { Mouse model of diabetes } \\
\text { (STZ-induced) }\end{array}$ & - Improved oxidative status & [55] & \\
\hline & & $\begin{array}{l}\text { Rats treated with } \\
\text { cyclophosphamide }\end{array}$ & $\begin{array}{l}\text { - Decreased oxidative stress } \\
\text { - } \quad \text { Enhanced the antioxidant defense system }\end{array}$ & [56] & \\
\hline & & Rats treated with sodium arsenite & $\begin{array}{l}\text { - Improved cognition } \\
\text { - } \quad \text { Decreased oxidative stress } \\
\text { - } \quad \text { Enhanced the antioxidant defense system }\end{array}$ & [57] & \\
\hline & & Rat model of $\mathrm{AD}$ ( $\mathrm{AlCl}_{3}$-induced) & $\begin{array}{l}\text { - Ameliorated hippocampal } \\
\text { neurodegeneration and cognitive } \\
\text { impairment } \\
\text { - } \quad \text { Decreased oxidative stress } \\
\text { - } \quad \text { Rescued the antioxidant defense system } \\
\text { - } \quad \text { Restored neurotransmitter levels }\end{array}$ & [58] & \\
\hline
\end{tabular}


Table 1. Cont.

\begin{tabular}{|c|c|c|c|c|c|}
\hline Phenolic Acids & Basic Description & Disease Models & Mode of Action & Ref. & Chemical Structure \\
\hline \multirow[t]{8}{*}{ Rosmarinic acid } & \multirow{8}{*}{$\begin{array}{l}\text { A polyphenol constituent of } \\
\text { many culinary herbs such as } \\
\text { rosemary, mint, and basil. From } \\
\text { the chemical point of view, it } \\
\text { represents a caffeic acid ester, } \\
\text { with tyrosine giving another } \\
\text { phenolic ring via } \\
\text { dihydroxyphenyl-lactic acid. }\end{array}$} & $\begin{array}{l}\text { Kindling mouse model } \\
\text { (PTZ-induced) }\end{array}$ & $\begin{array}{l}\text { - } \quad \text { Reduced the levels of free radicals and DNA } \\
\text { damage } \\
\text { - } \quad \text { Increased the latency } \\
\text { - } \quad \text { Decreased the percentage of seizure incidents }\end{array}$ & [22] & \\
\hline & & $\begin{array}{l}\text { Kindling mouse model (PTZ and } \\
\text { pilocarpine-induced) }\end{array}$ & $\begin{array}{l}\text { Improved the latency to first seizures } \\
\text { Reduced the latency to sleep in the } \\
\text { diazepam-induced sleeping time test } \\
\text { Decreased pilocarpine-induced genotoxic } \\
\text { damage }\end{array}$ & [23] & \\
\hline & & Rats exposed to noise & $\begin{array}{l}\text { - Attenuated hearing loss and hair cell damage } \\
\text { - } \quad \text { Reduced oxidative stress and lipid peroxidation } \\
\text { Enhanced the antioxidant machinery }\end{array}$ & [59] & \\
\hline & & C6 glial cells treated with $\mathrm{H}_{2} \mathrm{O}_{2}$ & $\begin{array}{l}\text { - } \quad \text { Reduced oxidative stress and lipid peroxidation } \\
\text { - Increased cell viability }\end{array}$ & {$[60,61]$} & \\
\hline & & Rat model of SCI & $\begin{array}{l}\text { Enhanced the antioxidant status } \\
\text { - } \quad \text { Decreased oxidative stress } \\
\text { - } \quad \text { Decreased inflammation }\end{array}$ & [62] & \\
\hline & & $\begin{array}{l}\text { Mouse model of a chronic } \\
\text { restraint stress }\end{array}$ & $\begin{array}{l}\text { Decreased p-tau and insoluble p-tau formation } \\
\text { Reverted the abnormal changes of chaperones } \\
\text { and Pin1 }\end{array}$ & [63] & \\
\hline & & $\begin{array}{l}\text { Rat organotypic hippocampal } \\
\text { slice cultures treated with } \\
\text { scopolamine }\end{array}$ & $\begin{array}{ll}\text { - } & \text { Enhanced LTP } \\
\text { - } & \text { Enhanced BDNF and GluR-2 protein expression } \\
\text { Enhanced cell survival rate }\end{array}$ & {$[64]$} & \\
\hline & & Rat model of neuropathic pain & - Decreased inflammation & [65] & \\
\hline
\end{tabular}


Table 1. Cont.

\begin{tabular}{|c|c|c|c|c|c|}
\hline Phenolic Acids & Basic Description & Disease Models & Mode of Action & Ref. & Chemical Structure \\
\hline \multirow[t]{5}{*}{ Acetylsalicylic acid } & \multirow{5}{*}{$\begin{array}{l}\text { A weakly acidic substance widely } \\
\text { used as a medication to reduce } \\
\text { pain, fever, as well as } \\
\text { inflammatory processes. } \\
\text { Chemically, it represents an } \\
\text { acetyl derivative of salicylic acid. }\end{array}$} & $\begin{array}{l}\text { Rats treated with } \\
\text { tetrachlorodibenzo-p-dioxin }\end{array}$ & - Decreased inflammation & [66] & \\
\hline & & HIV-1 transgenic rat & $\begin{array}{l}\text { - } \quad \text { Decreased inflammation } \\
\text { - } \quad \text { Decreased oxidative stress }\end{array}$ & [67] & \\
\hline & & Rat model of ischemia & $\begin{array}{l}\text { Improved learning and memory } \\
\text { - Counteracted infarction volume and neural } \\
\text { changes }\end{array}$ & [69] & \\
\hline & & $\begin{array}{l}\text { Mouse bone marrow-derived } \\
\text { immature dendritic cells treated } \\
\text { with LPS }\end{array}$ & $\begin{array}{l}\text { - } \quad \text { Reduced the number of mouse bone } \\
\text { marrow-derived immature dendritic cells } \\
\text { expressing CD40 protein and MHCII }\end{array}$ & [70] & \\
\hline & & BV-2 cells treated with LPS & $\begin{array}{l}\text { - Enhanced the expression of TfR1 and Fpn1 } \\
\text { - } \quad \text { Decreased the levels of ferritin contents } \\
\text { Decreased inflammation }\end{array}$ & [71] & \\
\hline
\end{tabular}


Table 1. Cont.

\begin{tabular}{|c|c|c|c|c|c|}
\hline Phenolic Acids & Basic Description & Disease Models & Mode of Action & Ref. & Chemical Structure \\
\hline \multirow[t]{3}{*}{ Tannic acid } & $\begin{array}{l}\text { A specific form of tannins, a class } \\
\text { of astringent, polyphenolic } \\
\text { biomolecules, characterized by a } \\
\text { very efficient metal chelating } \\
\text { activity. }\end{array}$ & N/A (untreated rats) & $\begin{array}{l}\text { - Elevated the concentrations of NMDA } \\
\text { receptors } \\
\text { - } \quad \text { Enhanced the antioxidant machinery } \\
\text { - Decreased lipid peroxidation }\end{array}$ & [72] & \\
\hline & & Rats treated with lead acetate & $\begin{array}{l}\text { - Decreased the neurochemical perturbations } \\
\text { - } \quad \text { Decreased oxidative damage } \\
\text { - Restored antioxidant status }\end{array}$ & [73] & \\
\hline & & Rat model of MCAO & $\begin{array}{l}\text { - Counteracted behavioral deficits and } \\
\text { improved neurological function } \\
\text { - } \quad \text { Decreased neurodegeneration } \\
\text { - Reduced infarct size }\end{array}$ & [75] & \\
\hline
\end{tabular}


Table 1. Cont.

\begin{tabular}{|c|c|c|c|c|c|}
\hline Phenolic Acids & Basic Description & Disease Models & Mode of Action & Ref. & Chemical Structure \\
\hline \multirow[t]{9}{*}{ Protocatechuic acid } & \multirow{9}{*}{$\begin{array}{l}\text { A dihydroxybenzoic acid } \\
\text { representing a major metabolite } \\
\text { of antioxidant polyphenols found } \\
\text { in green tea. It also possesses } \\
\text { anti-inflammatory properties. }\end{array}$} & PC12 cells treated with $\mathrm{H}_{2} \mathrm{O}_{2}$ & $\begin{array}{l}\text { - Modulated apoptotic mediators } \\
\text { - } \quad \text { Enhanced the antioxidant defense }\end{array}$ & [76] & \\
\hline & & PC12 cells treated with MPP+ & $\begin{array}{l}\text { - Suppressed mitochondrial dysfunction and apoptotic } \\
\text { cell death } \\
\text { - } \quad \text { Decreased oxidative stress } \\
\text { - } \quad \text { Enhanced the antioxidant defense }\end{array}$ & [77] & \\
\hline & & PC12 cells treated ROT & $\begin{array}{l}\text { - Ameliorated mitochondrial dysfunction } \\
\text { - Suppressed apoptotic cell death }\end{array}$ & [78] & \\
\hline & & $\begin{array}{l}\text { Zebrafish, mice, and PC12 treated } \\
\text { with 6-OHDA }\end{array}$ & $\begin{array}{l}\text { - Protocatechuic acid in combination with chrysin } \\
\text { - } \quad \text { Prevented neuronal loss in both zebrafish and mice } \\
\text { encreased cell viability, decreased oxidative stress, } \\
\text { inflammation in PC12 cells }\end{array}$ & [79] & \\
\hline & & BV2 cells treated with LPS & $\begin{array}{l}\text { - Modulated NF-kB and MAPKs signaling pathways } \\
\text { - Decreased inflammation }\end{array}$ & [80] & \\
\hline & & $\begin{array}{l}\text { Rat model of diabetes } \\
\text { (STZ-induced) }\end{array}$ & $\begin{array}{l}\text { - } \quad \text { Exerted glycemic control } \\
\text { - } \quad \text { Attenuated brain mitochondrial dysfunction } \\
\text { - Decreased oxidative stress }\end{array}$ & [81] & \\
\hline & & $\begin{array}{l}\text { Cerebellar granule neurons } \\
\text { treated with } \mathrm{H}_{2} \mathrm{O}_{2} \text { and BV2 cells } \\
\text { treated with LPS }\end{array}$ & $\begin{array}{l}\text { - Decreased nitrosative stress and neurodegeneration in } \\
\text { cerebellar granule neurons } \\
\text { - Decreased inflammation in BV-2 cells }\end{array}$ & [82] & \\
\hline & & $\begin{array}{l}\text { Mice treated with sodium } \\
\text { arsenate }\end{array}$ & $\begin{array}{l}\text { - Decreased lipid peroxidation and oxidative stress } \\
\text { - } \quad \text { Decreased inflammation } \\
\text { - Attenuated histopathological changes }\end{array}$ & [83] & \\
\hline & & $\begin{array}{l}\text { PC12 cells treated with } A \beta \text { and } \\
\alpha \text {-Syn }\end{array}$ & $\begin{array}{l}\text { - } \quad \text { Prevented cell death } \\
\text { - Inhibited the aggregation of } A \beta \text { and } \alpha \text {-Syn }\end{array}$ & [84] & \\
\hline
\end{tabular}


Table 1. Cont.

\begin{tabular}{|c|c|c|c|c|c|}
\hline Phenolic Acids & Basic Description & Disease Models & Mode of Action & Ref. & Chemical Structure \\
\hline \multirow[t]{5}{*}{ p-coumaric acid } & \multirow{5}{*}{$\begin{array}{l}\text { A hydroxycinnamic acid } \\
\text { representing the hydroxy } \\
\text { derivative of cinnamic acid. } \\
\text { Among the three isomers of } \\
\text { coumaric acid (o-, m-, and } \\
\text { p-coumaric acid), p-coumaric } \\
\text { acid represents the most } \\
\text { abundant isomer that can found } \\
\text { in nature. }\end{array}$} & Rat model of SNI & $\begin{array}{l}\text { - } \quad \begin{array}{l}\text { Reduced oxidative stress and axonal } \\
\text { degeneration }\end{array} \\
\text { Enhanced the antioxidant defense }\end{array}$ & [86] & 0 \\
\hline & & Rat model of SCI & $\begin{array}{l}\text { - } \quad \text { Reduced ischemic fiber degeneration } \\
\text { - } \quad \text { Deduced } A \beta \text { protein accumulation } \\
\text { Decreased neuroinflammation }\end{array}$ & [87] & \\
\hline & & $\begin{array}{l}\text { Rat model of embolic cerebral } \\
\text { ischemia }\end{array}$ & $\begin{array}{l}\text { - Modulated apoptotic mediators } \\
\text { - } \quad \text { Decreased lipid peroxidation }\end{array}$ & [88] & \\
\hline & & $\begin{array}{l}\text { Rat model of } \\
\text { ischemia/reperfusion injury }\end{array}$ & $\begin{array}{l}\text { - Decreased lipid peroxidation } \\
\text { - } \quad \text { Enhanced the antioxidant defense } \\
\text { Decreased infarction size and hippocampal } \\
\text { neuronal death }\end{array}$ & [89] & \\
\hline & & Mice treated with LPS & $\begin{array}{l}\text { - } \quad \text { Modulated apoptotic mediators } \\
\text { - } \quad \text { Decreased lipid peroxidation }\end{array}$ & [90] & \\
\hline
\end{tabular}


Table 1. Cont.

\begin{tabular}{|c|c|c|c|c|c|}
\hline Phenolic Acids & Basic Description & Disease Models & Mode of Action & Ref. & Chemical Structure \\
\hline \multirow[t]{4}{*}{ Sinapic acid } & \multirow{4}{*}{$\begin{array}{l}\text { A small naturally occurring } \\
\text { hydroxycinnamic acid belonging } \\
\text { to the phenylpropanoid family. } \\
\text { Due to its well-known ability to } \\
\text { absorb laser radiation and donate } \\
\text { protons to the analyte of interest, } \\
\text { it is frequently used as a matrix } \\
\text { in MALDI mass spectrometry } \\
\text { experiments. }\end{array}$} & $\begin{array}{l}\text { Mouse model of AD } \\
\text { (A } \beta \text {-induced) }\end{array}$ & $\begin{array}{l}\text { - } \quad \text { Rescued neuronal cell death at CA1 region level } \\
\text { - } \quad \text { Attenuated oxidative and nitrosative stress } \\
\text { - } \quad \text { Attenuated memory impairment } \\
\text { glial cell activation }\end{array}$ & [93] & o \\
\hline & & $\begin{array}{l}\text { Rat model of early PD } \\
\text { (6-OHDA-induced) }\end{array}$ & $\begin{array}{l}\text { - Improved turning behavior } \\
\text { - } \quad \text { Counteracted the loss of dopaminergic neurons } \\
\text { at substantia nigra pars compacta level } \\
\text { - } \quad \text { Lowered iron reactivity } \\
\text { Attenuated oxidative stress }\end{array}$ & [94] & \\
\hline & & $\begin{array}{l}\text { Rat model of global cerebral } \\
\text { ischemia }\end{array}$ & $\begin{array}{l}\text { - } \quad \text { Prevented neuronal damage } \\
\text { - } \quad \text { Reduced memory impairment }\end{array}$ & [95] & \\
\hline & & Mice treated with kainic acid & $\begin{array}{ll}\text { - } & \text { Prevented neuronal damage } \\
\text { - } \quad \text { Reduced reactive gliosis } \\
\text { - } \quad \text { Eeduced oxidative and nitrosative stress } \\
\text { - }\end{array}$ & [96] & \\
\hline
\end{tabular}


Table 1. Cont.

\begin{tabular}{|c|c|c|c|c|c|}
\hline Phenolic Acids & Basic Description & Disease Models & Mode of Action & Ref. & Chemical Structure \\
\hline \multirow[t]{5}{*}{ Ellagic acid } & \multirow[t]{5}{*}{$\begin{array}{l}\text { An organic heterotetracyclic } \\
\text { compound found in different } \\
\text { fruits and vegetables. From the } \\
\text { chemical point of view, it } \\
\text { represents the dilactone of } \\
\text { hexahydroxydiphenic acid. }\end{array}$} & $\begin{array}{l}\text { Rat model of sporadic AD } \\
\text { (STZ-induced) }\end{array}$ & $\begin{array}{ll}\text { - } & \text { Reduced oxidative stress } \\
\text { - } & \text { Reduced inflammation } \\
\text { - } & \text { Reduced AchE and A } \beta \text { plaque levels } \\
\text { - } \quad \begin{array}{l}\text { Normalized sporadic AD-associated } \\
\text { abnormal behavioral representations }\end{array}\end{array}$ & [97] & \\
\hline & & $\begin{array}{l}\text { Rat models of scopolamine- and } \\
\text { diazepam-induced cognitive } \\
\text { impairments }\end{array}$ & $\begin{array}{l}\text { - Prevented scopolamine- and } \\
\text { diazepam-induced cognitive impairments }\end{array}$ & [98] & ОН \\
\hline & & $\begin{array}{l}\text { Rat model of nerve injury } \\
\text { (photothrombosis-induced) and } \\
\text { OGD/R model in neural stem } \\
\text { cells }\end{array}$ & $\begin{array}{l}\text { Improved the rats' nerve-related abilities, } \\
\text { remedied infarct volumes and } \\
\text { morphological changes in the brain, and } \\
\text { enhanced the content of nestin protein in } \\
\text { the brain semidarkness zone } \\
\text { Improved cell proliferation and } \\
\text { neurorestoration through the activation of } \\
\text { the } W n t / \beta \text {-catenin signaling pathway }\end{array}$ & [99] & \\
\hline & & $\begin{array}{l}\text { Rat model of PD } \\
\text { (6-OHDA-induced) }\end{array}$ & $\begin{array}{l}\text { - } \quad \text { Restored the locomotion } \\
\text { Decreased inflammation in striatum and } \\
\text { hippocampus }\end{array}$ & [100] & \\
\hline & & $\begin{array}{l}\text { Rat model of neonatal } \\
\text { hypoxic-ischemic brain injury }\end{array}$ & $\begin{array}{l}\text { - Reduced infarct size, volume and tissue loss } \\
\text { - } \quad \begin{array}{l}\text { Decreased neurodegeneration and } \\
\text { inflammation }\end{array} \\
\text { - Down-regulated MAPK proteins } \\
\text { - Modulated apoptotic mediators }\end{array}$ & [101] & \\
\hline
\end{tabular}


Table 1. Cont.

Phenolic Acids

Salicylic acid Basic Description

A plant hormone representing a

precursor to and a metabolite o

acetylsalicylic acid (commonly

known as aspirin).

\section{Disease Models}

Mice treated with METH

\section{Mode of Action}

- Decreased oxidative stress

- Reverted mitochondrial dysfunction and

ameliorated complex-I activity

- Decreased neurotoxicity

- Blocked behavioral changes related to movement abnormalities
Ref.

[102]

Chemical Structure

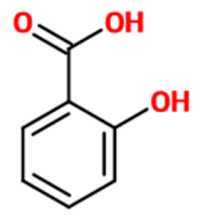

Primary cortex neurons treated

with paclitaxel and cisplatin

- Decreased cell death

Increased total antioxidant capacity

- Decreased oxidative stress 
Table 1. Cont.

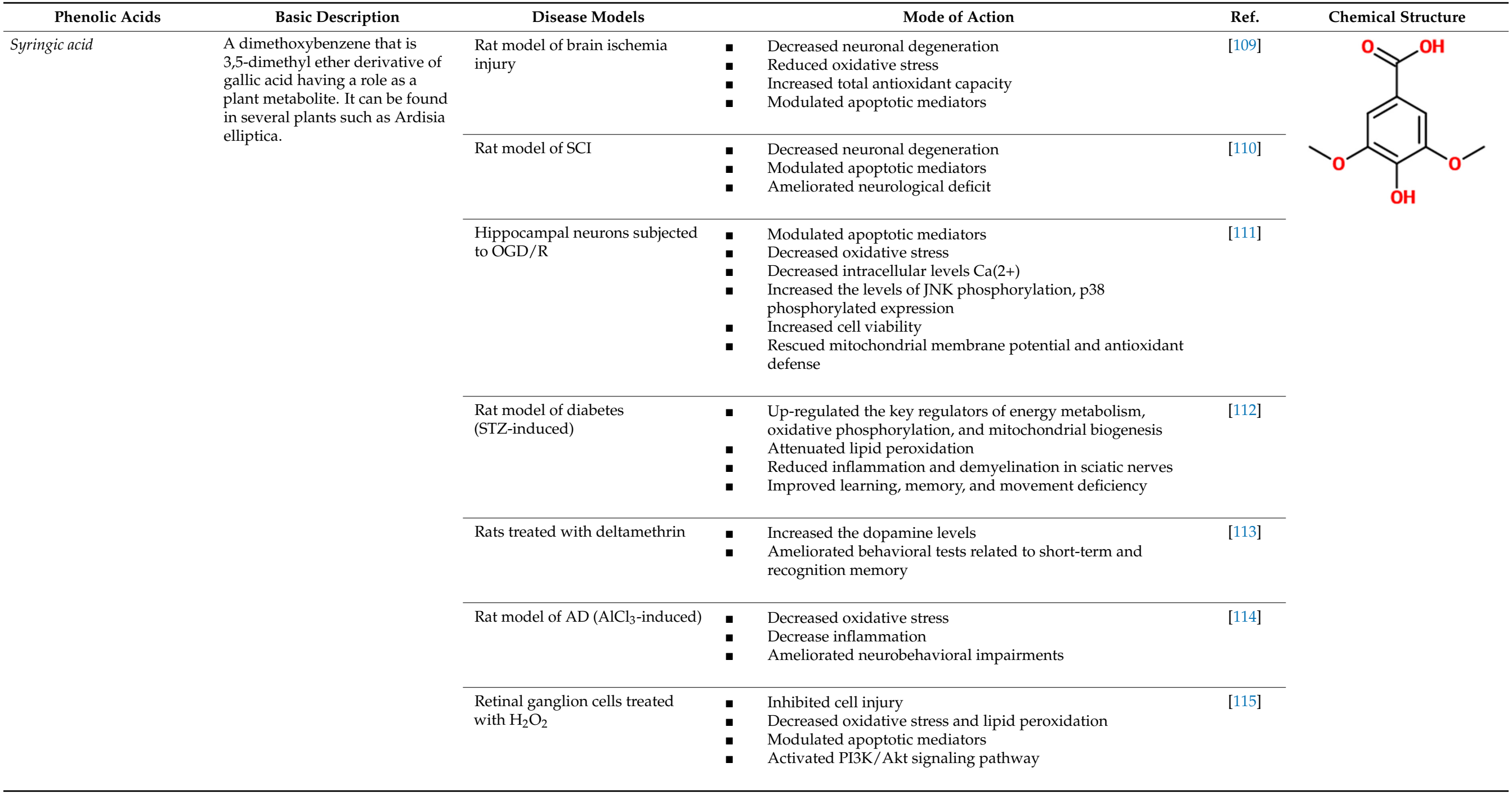


Table 1. Cont.

\begin{tabular}{|c|c|c|c|c|c|}
\hline Phenolic Acids & Basic Description & Disease Models & Mode of Action & Ref. & Chemical Structure \\
\hline \multirow[t]{8}{*}{ Cinnamic aldehyde } & \multirow{8}{*}{$\begin{array}{l}\text { A phenylpropanoid synthesized } \\
\text { by the shikimate pathway giving } \\
\text { to cinnamon its characteristic } \\
\text { flavor and odor. It can be found } \\
\text { in the bark of cinnamon trees as } \\
\text { well as other species of the genus } \\
\text { Cinnamomum. }\end{array}$} & $\begin{array}{l}\text { Mouse model of PD } \\
\text { (MPTP-induced) and BE(2)-M17 } \\
\text { cells treated with MPTP }\end{array}$ & $\begin{array}{l}\text { Inhibited autophagy and prevented the selective } \\
\text { dopaminergic neuronal death in the substantia nigra } \\
\text { Decreased autophagy and recovered MPP+-induced cell } \\
\text { death in BE(2)-M17 cells }\end{array}$ & [117] & \\
\hline & & $\begin{array}{l}\text { Mouse model of permanent } \\
\text { cerebral ischemia }\end{array}$ & $\begin{array}{l}\text { - Reduced neurological deficit scores, brain edema, and } \\
\text { infarct volume } \\
\text { - Decreased inflammation } \\
\text { - Reduced the infiltration of leukocytes into the ischaemic } \\
\text { brain }\end{array}$ & [118] & \\
\hline & & $\begin{array}{l}\text { Rabbit model of early brain } \\
\text { injury (subarachnoid } \\
\text { hemorrhage-induced) }\end{array}$ & $\begin{array}{l}\text { - Attenuated cerebral vasospasm } \\
\text { - Increased the cross-sectional areas of the basilar artery and } \\
\text { reduced the arterial wall thickness } \\
\text { - Lowered hippocampal degeneration scores }\end{array}$ & [119] & \\
\hline & & SH-SY5Y cells treated with $A \beta$ & $\begin{array}{ll}\text { - } & \text { Reverted cell toxicity } \\
\text { - } & \text { Suppressed the activation of GSK-3 } \beta\end{array}$ & [120] & \\
\hline & & PC-12 cells treated with METH & $\begin{array}{l}\text { - } \quad \text { Attenuated cell viability loss } \\
\text { - } \quad \text { Decreased oxidative stress } \\
\text { - } \quad \text { Modulated apoptotic mediators }\end{array}$ & [121] & \\
\hline & & Aged rats treated with METH & $\begin{array}{l}\text { - } \quad \text { Attenuated aging-induced memory impairment } \\
\text { - } \quad \text { Decreased oxidative stress } \\
\text { - } \quad \text { Modulated apoptotic mediators }\end{array}$ & [122] & \\
\hline & & Rat model TBI & $\begin{array}{l}\text { - } \quad \text { Decreased neutrophil recruitment } \\
\text { - } \quad \text { Decreased oxidative stress } \\
\text { dysfunction }\end{array}$ & [123] & \\
\hline & & $\begin{array}{l}\text { Mice subjected to acute or } \\
\text { chronic stress }\end{array}$ & - Decreased anxiety-related behavior in mice & [124] & \\
\hline
\end{tabular}


Table 1 does not include the findings related to homovanillic acid, a methoxyphenol for which only human studies not describing the mode of action related to neuroprotection were reported.

\subsection{Phenolic Acids Potential in Drug Discovery}

Natural products, including phenolic acids, represent an important and wide source of new lead compounds in drug discovery and development. Unfortunately, the discovery of potential "hits" (lead molecules) is a complex and very challenging process, requiring the evaluation of numerous parameters during drug candidate selection (e.g., safety, pharmacokinetics, and efficacy) along with a considerable economic effort and a large workforce [125]. Among compounds of natural origin, phenolic acids, due to their phenol moiety coupled to the resonance-stabilized structure, possess a strong antioxidant activity often accomplished via a radical scavenging mechanism. The antioxidant activity together with those previously mentioned such as anti-inflammatory and anti-aggregant activities (see Table 1), make phenolic acids an excellent starting point for the synthesis of new drugs characterized by a multimodal mechanism of action. Different research groups are currently employing conventional and innovative drug discovery strategies such as microfluidics [126] and computer-aided drug design [125] to isolate and elucidate the structure of natural phenolic acids with prominent biological activity, to study the structure-activity-relationship (SAR) of novel phenolic acids characterized by a high pharmacological potential [127], and to synthesize new bioactive molecules based on naturally occurring phenolic acids and/or their derivatives [128].

\section{Conclusions}

In conclusion, recent evidence suggests that phenolic acids may exert neuroprotective effects targeting multiple cellular pathways involved in the pathophysiology of cognitive disorders. Since the results from in vivo reports are an indicator of potential mechanisms, it is important that future studies would be able to replicate the findings at the clinical level using food sources of phenolic acids or nutraceutics with clinically relevant doses. Moreover, future studies should also take into account that phenolic acids undergo metabolism and transformation by the gut microbiota into bioavailable molecules, whose effects and effectiveness may differ. Although the pharmacokinetic properties of phenolic acids are considerable, and they can easily reach the brain at therapeutically-relevant levels, future translational studies should also investigate which among the different metabolites generated from phenolic acid consumption may be responsible for the potential neuroprotective effects of this group of polyphenols in the treatment of cognitive disorders.

Author Contributions: G.C., J.G., A.P., G.L., S.C., A.C., O.B., R.F., F.C. and G.G. have made a substantial, direct, and intellectual contribution to the review. All authors have read and agreed to the published version of the manuscript.

Funding: The study was a part of the ADICOS (Association between DIetary factors and COgnitive Status) project funded by the "PIAno di inCEntivi per la RIcerca di Ateneo 2020/2022-Starting Grant" of the University of Catania, Italy (G.G.).

Institutional Review Board Statement: Not applicable.

Informed Consent Statement: Not applicable.

Data Availability Statement: Not applicable.

Acknowledgments: The figures have been generated by using Servier Medical Art available at smart.servier.com (accessed on 6 June 2021).

Conflicts of Interest: The authors declare no conflict of interest. The funders had no role in the design and reporting of the study. 


\section{References}

1. Godos, J.; Currenti, W.; Angelino, D.; Mena, P.; Castellano, S.; Caraci, F.; Galvano, F.; Del Rio, D.; Ferri, R.; Grosso, G. Diet and mental health: Review of the recent updates on molecular mechanisms. Antioxidants 2020, 9, 346. [CrossRef] [PubMed]

2. Caruso, G.; Torrisi, S.A.; Mogavero, M.P.; Currenti, W.; Castellano, S.; Godos, J.; Ferri, R.; Galvano, F.; Leggio, G.M.; Grosso, G.; et al. Polyphenols and neuroprotection: Therapeutic implications for cognitive decline. Pharmacol. Ther. 2021, 108013. [CrossRef] [PubMed]

3. Del Rio, D.; Rodriguez-Mateos, A.; Spencer, J.P.E.; Tognolini, M.; Borges, G.; Crozier, A. Dietary (poly)phenolics in human health: Structures, bioavailability, and evidence of protective effects against chronic diseases. Antioxid. Redox Signal. 2013, 18, 1818-1892. [CrossRef]

4. Spencer, J.P.E. The impact of flavonoids on memory: Physiological and molecular considerations. Chem. Soc. Rev. 2009, 38, 1152-1161. [CrossRef]

5. Zhao, B. Natural antioxidants protect neurons in Alzheimer's disease and Parkinson's disease. Neurochem. Res. 2009, 34, 630-638. [CrossRef] [PubMed]

6. Spencer, J.P.E. Flavonoids and brain health: Multiple effects underpinned by common mechanisms. Genes Nutr. 2009, 4, 243-250. [CrossRef]

7. Hamaguchi, T.; Ono, K.; Murase, A.; Yamada, M. Phenolic compounds prevent Alzheimer's pathology through different effects on the amyloid-beta aggregation pathway. Am. J. Pathol. 2009, 175, 2557-2565. [CrossRef]

8. Ardah, M.T.; Paleologou, K.E.; Lv, G.; Abul Khair, S.B.; Kazim, A.S.; Minhas, S.T.; Al-Tel, T.H.; Al-Hayani, A.A.; Haque, M.E.; Eliezer, D.; et al. Structure activity relationship of phenolic acid inhibitors of $\alpha$-synuclein fibril formation and toxicity. Front. Aging Neurosci. 2014, 6, 197. [CrossRef]

9. Freyssin, A.; Page, G.; Fauconneau, B.; Rioux Bilan, A. Natural polyphenols effects on protein aggregates in Alzheimer's and Parkinson's prion-like diseases. Neural Regen. Res. 2018, 13, 955-961. [CrossRef]

10. Szwajgier, D.; Borowiec, K.; Pustelniak, K. The neuroprotective effects of phenolic acids: Molecular mechanism of action. Nutrients 2017, 9, 477. [CrossRef]

11. Grasso, M.; Caruso, G.; Godos, J.; Bonaccorso, A.; Carbone, C.; Castellano, S.; Currenti, W.; Grosso, G.; Musumeci, T.; Caraci, F Improving Cognition with Nutraceuticals Targeting TGF- $\beta 1$ Signaling. Antioxidants 2021, 10, 1075. [CrossRef]

12. Szwajgier, D.; Baranowska-Wojcik, E.; Borowiec, K. Phenolic Acids Exert Anticholinesterase and Cognition-Improving Effects. Curr. Alzheimer Res. 2018, 15, 531-543. [CrossRef]

13. Manach, C.; Scalbert, A.; Morand, C.; Rémésy, C.; Jiménez, L. Polyphenols: Food sources and bioavailability. Am. J. Clin. Nutr. 2004, 79, 727-747. [CrossRef]

14. Kesse-Guyot, E.; Fezeu, L.; Andreeva, V.A.; Touvier, M.; Scalbert, A.; Hercberg, S.; Galan, P. Total and specific polyphenol intakes in midlife are associated with cognitive function measured 13 years later. J. Nutr. 2012, 142, 76-83. [CrossRef]

15. Goni, L.; Fernández-Matarrubia, M.; Romanos-Nanclares, A.; Razquin, C.; Ruiz-Canela, M.; Martínez-González, M.Á.; Toledo, E. Polyphenol intake and cognitive decline in the Seguimiento Universidad de Navarra (SUN) Project. Br. J. Nutr. 2021, 126, 43-52. [CrossRef]

16. Godos, J.; Caraci, F.; Micek, A.; Castellano, S.; D’Amico, E.; Paladino, N.; Ferri, R.; Galvano, F.; Grosso, G. Dietary Phenolic Acids and Their Major Food Sources Are Associated with Cognitive Status in Older Italian Adults. Antioxidants 2021, 10, 700. [CrossRef]

17. Ran, L.S.; Liu, W.H.; Fang, Y.Y.; Xu, S.B.; Li, J.; Luo, X.; Pan, D.J.; Wang, M.H.; Wang, W. Alcohol, coffee and tea intake and the risk of cognitive deficits: A dose-response meta-analysis. Epidemiol. Psychiatr. Sci. 2021, 30, e13. [CrossRef]

18. Basu Mallik, S.; Mudgal, J.; Nampoothiri, M.; Hall, S.; Dukie, S.A.; Grant, G.; Rao, C.M.; Arora, D. Caffeic acid attenuates lipopolysaccharide-induced sickness behaviour and neuroinflammation in mice. Neurosci. Lett. 2016, 632, 218-223. [CrossRef]

19. Caruso, G.; Fresta, C.G.; Grasso, M.; Santangelo, R.; Lazzarino, G.; Lunte, S.M.; Caraci, F. Inflammation as the common biological link between depression and cardiovascular diseases: Can carnosine exert a protective role? Curr. Med. Chem. 2020, 27, 1782-1800. [CrossRef]

20. Di Pietro, V.; Yakoub, K.M.; Caruso, G.; Lazzarino, G.; Signoretti, S.; Barbey, A.K.; Tavazzi, B.; Lazzarino, G.; Belli, A.; Amorini, A.M. Antioxidant therapies in traumatic brain injury. Antioxidants 2020, 9, 260. [CrossRef]

21. Fazili, N.A.; Naeem, A. Anti-fibrillation potency of caffeic acid against an antidepressant induced fibrillogenesis of human $\alpha$-synuclein: Implications for Parkinson's disease. Biochimie 2015, 108, 178-185. [CrossRef] [PubMed]

22. Coelho, V.R.; Vieira, C.G.; de Souza, L.P.; Moysés, F.; Basso, C.; Papke, D.K.M.; Pires, T.R.; Siqueira, I.R.; Picada, J.N.; Pereira, P. Antiepileptogenic, antioxidant and genotoxic evaluation of rosmarinic acid and its metabolite caffeic acid in mice. Life Sci. 2015, 122, 65-71. [CrossRef]

23. Coelho, V.R.; Vieira, C.G.; de Souza, L.P.; da Silva, L.L.; Pflüger, P.; Regner, G.G.; Papke, D.K.M.; Picada, J.N.; Pereira, P. Behavioral and genotoxic evaluation of rosmarinic and caffeic acid in acute seizure models induced by pentylenetetrazole and pilocarpine in mice. Naunyn Schmiedebergs Arch. Pharmacol. 2016, 389, 1195-1203. [CrossRef] [PubMed]

24. Chang, W.; Huang, D.; Lo, Y.M.; Tee, Q.; Kuo, P.; Wu, J.S.; Huang, W.; Shen, S. Protective Effect of Caffeic Acid against Alzheimer's Disease Pathogenesis via Modulating Cerebral Insulin Signaling, $\beta$-Amyloid Accumulation, and Synaptic Plasticity in Hyperinsulinemic Rats. J. Agric. Food Chem. 2019, 67, 7684-7693. [CrossRef] 
25. Alkis, H.E.; Kuzhan, A.; Dirier, A.; Tarakcioglu, M.; Demir, E.; Saricicek, E.; Demir, T.; Ahlatci, A.; Demirci, A.; Cinar, K. Neuroprotective effects of propolis and caffeic acid phenethyl ester (CAPE) on the radiation-injured brain tissue (Neuroprotective effects of propolis and CAPE). Int. J. Radiat. Res. 2015, 13, 297-303.

26. Armutcu, F.; Akyol, S.; Ustunsoy, S.; Turan, F.F. Therapeutic potential of caffeic acid phenethyl ester and its anti-inflammatory and immunomodulatory effects (Review). Exp. Ther. Med. 2015, 9, 1582-1588. [CrossRef] [PubMed]

27. Tsai, C.-F.; Kuo, Y.-H.; Yeh, W.-L.; Wu, C.Y.-J.; Lin, H.-Y.; Lai, S.-W.; Liu, Y.-S.; Wu, L.-H.; Lu, J.-K.; Lu, D.-Y. Regulatory effects of caffeic acid phenethyl ester on neuroinflammation in microglial cells. Int. J. Mol. Sci. 2015, 16, 5572-5589. [CrossRef] [PubMed]

28. Ginis, Z.; Ozturk, G.; Albayrak, A.; Kurt, S.N.; Albayrak, M.; Fadillioglu, E. Protective effects of caffeic acid phenethyl ester on ifosfamide-induced central neurotoxicity in rats. Toxicol. Ind. Health 2016, 32, 337-343. [CrossRef]

29. Akyol, S.; Erdemli, H.K.; Armutcu, F.; Akyol, O. In vitro and in vivo neuroprotective effect of caffeic acid phenethyl ester. J. Intercult. Ethnopharmacol. 2015, 4, 192-193. [CrossRef]

30. Dos Santos, N.A.G.; Martins, N.M.; Silva, R.d.B.; Ferreira, R.S.; Sisti, F.M.; dos Santos, A.C. Caffeic acid phenethyl ester (CAPE) protects PC12 cells from MPP+ toxicity by inducing the expression of neuron-typical proteins. Neurotoxicology 2014, 45, 131-138. [CrossRef]

31. Bak, J.; Kim, H.J.; Kim, S.Y.; Choi, Y.-S. Neuroprotective effect of caffeic acid phenethyl ester in 3-nitropropionic acid-induced striatal neurotoxicity. Korean J. Physiol. Pharmacol. 2016, 20, 279-286. [CrossRef]

32. Mikami, Y.; Yamazawa, T. Chlorogenic acid, a polyphenol in coffee, protects neurons against glutamate neurotoxicity. Life Sci. 2015, 139, 69-74. [CrossRef] [PubMed]

33. Guo, Y.-J.; Luo, T.; Wu, F.; Mei, Y.-W.; Peng, J.; Liu, H.; Li, H.-R.; Zhang, S.-L.; Dong, J.-H.; Fang, Y.; et al. Involvement of TLR2 and TLR9 in the anti-inflammatory effects of chlorogenic acid in HSV-1-infected microglia. Life Sci. 2015, 127, 12-18. [CrossRef] [PubMed]

34. Wu, J.; Chen, H.; Li, H.; Tang, Y.; Yang, L.; Cao, S.; Qin, D. Antidepressant Potential of Chlorogenic Acid-Enriched Extract from Eucommia ulmoides Oliver Bark with Neuron Protection and Promotion of Serotonin Release through Enhancing Synapsin I Expression. Molecules 2016, 21, 260. [CrossRef]

35. Gul, Z.; Demircan, C.; Bagdas, D.; Buyukuysal, R.L. Protective Effects of Chlorogenic Acid and its Metabolites on Hydrogen Peroxide-Induced Alterations in Rat Brain Slices: A Comparative Study with Resveratrol. Neurochem. Res. 2016, 41, $2075-2085$. [CrossRef]

36. Aseervatham, G.S.B.; Suryakala, U.; Doulethunisha; Sundaram, S.; Bose, P.C.; Sivasudha, T. Expression pattern of NMDA receptors reveals antiepileptic potential of apigenin 8-C-glucoside and chlorogenic acid in pilocarpine induced epileptic mice. Biomed. Pharmacother. 2016, 82, 54-64. [CrossRef]

37. Fang, S.-Q.; Wang, Y.-T.; Wei, J.-X.; Shu, Y.-H.; Xiao, L.; Lu, X.-M. Beneficial effects of chlorogenic acid on alcohol-induced damage in PC12 cells. Biomed. Pharmacother. 2016, 79, 254-262. [CrossRef]

38. Taram, F.; Winter, A.N.; Linseman, D.A. Neuroprotection comparison of chlorogenic acid and its metabolites against mechanistically distinct cell death-inducing agents in cultured cerebellar granule neurons. Brain Res. 2016, 1648, 69-80. [CrossRef]

39. Chen, J.; Lin, D.; Zhang, C.; Li, G.; Zhang, N.; Ruan, L.; Yan, Q.; Li, J.; Yu, X.; Xie, X.; et al. Antidepressant-like effects of ferulic acid: Involvement of serotonergic and norepinergic systems. Metab. Brain Dis. 2015, 30, 129-136. [CrossRef]

40. Lenzi, J.; Rodrigues, A.F.; Rós, A.d.S.; de Castro, A.B.; de Lima, D.D.; Magro, D.D.D.; Zeni, A.L.B. Ferulic acid chronic treatment exerts antidepressant-like effect: Role of antioxidant defense system. Metab. Brain Dis. 2015, 30, 1453-1463. [CrossRef]

41. Ojha, S.; Javed, H.; Azimullah, S.; Abul Khair, S.B.; Haque, M.E. Neuroprotective potential of ferulic acid in the rotenone model of Parkinson's disease. Drug Des. Devel. Ther. 2015, 9, 5499-5510. [CrossRef]

42. Huang, F.; Deng, H.-M.; Zhu, M.-M.; Xiao, F.; Yang, L.; Zhang, Z.-J.; Xiao, Y.; Nie, H. Inhibitory effect of ferulic acid on inflammatory response in microglia induced by lipopolysaccharides. Zool. Res. 2011, 32, 311-316. [CrossRef]

43. Dong, G.-C.; Kuan, C.-Y.; Subramaniam, S.; Zhao, J.-Y.; Sivasubramaniam, S.; Chang, H.-Y.; Lin, F.-H. A potent inhibition of oxidative stress induced gene expression in neural cells by sustained ferulic acid release from chitosan based hydrogel. Mater. Sci. Eng. C 2015, 49, 691-699. [CrossRef]

44. Liu, Y.-M.; Hu, C.-Y.; Shen, J.-D.; Wu, S.-H.; Li, Y.-C.; Yi, L.-T. Elevation of synaptic protein is associated with the antidepressant-like effects of ferulic acid in a chronic model of depression. Physiol. Behav. 2017, 169, 184-188. [CrossRef]

45. Huang, H.; Hong, Q.; Tan, H.-L.; Xiao, C.-R.; Gao, Y. Ferulic acid prevents LPS-induced up-regulation of PDE4B and stimulates the cAMP/CREB signaling pathway in PC12 cells. Acta Pharmacol. Sin. 2016, 37, 1543-1554. [CrossRef]

46. Koh, P.-O. Ferulic acid attenuates the down-regulation of MEK/ERK/p90RSK signaling pathway in focal cerebral ischemic injury. Neurosci. Lett. 2015, 588, 18-23. [CrossRef]

47. Lin, W.-C.; Peng, Y.-F.; Hou, C.-W. Ferulic acid protects PC12 neurons against hypoxia by inhibiting the p-MAPKs and COX-2 pathways. Iran. J. Basic Med. Sci. 2015, 18, 478-484.

48. Kim, M.-J.; Seong, A.-R.; Yoo, J.-Y.; Jin, C.-H.; Lee, Y.-H.; Kim, Y.J.; Lee, J.; Jun, W.J.; Yoon, H.-G. Gallic acid, a histone acetyltransferase inhibitor, suppresses $\beta$-amyloid neurotoxicity by inhibiting microglial-mediated neuroinflammation. Mol. Nutr. Food Res. 2011, 55, 1798-1808. [CrossRef]

49. Mirshekar, M.A.; Sarkaki, A.; Farbood, Y.; Gharib Naseri, M.K.; Badavi, M.; Mansouri, M.T.; Haghparast, A. Neuroprotective effects of gallic acid in a rat model of traumatic brain injury: Behavioral, electrophysiological, and molecular studies. Iran. J. Basic Med. Sci. 2018, 21, 1056-1063. [CrossRef] 
50. Mori, T.; Koyama, N.; Yokoo, T.; Segawa, T.; Maeda, M.; Sawmiller, D.; Tan, J.; Town, T. Gallic acid is a dual $\alpha / \beta$-secretase modulator that reverses cognitive impairment and remediates pathology in Alzheimer mice. J. Biol. Chem. 2020, 295, 16251-16266. [CrossRef]

51. Mattson, M.P.; Cheng, B.; Culwell, A.R.; Esch, F.S.; Lieberburg, I.; Rydel, R.E. Evidence for excitoprotective and intraneuronal calcium-regulating roles for secreted forms of the beta-amyloid precursor protein. Neuron 1993, 10, 243-254. [CrossRef]

52. Ishida, A.; Furukawa, K.; Keller, J.N.; Mattson, M.P. Secreted form of beta-amyloid precursor protein shifts the frequency dependency for induction of LTD, and enhances LTP in hippocampal slices. Neuroreport 1997, 8, 2133-2137. [CrossRef] [PubMed]

53. Yu, M.; Chen, X.; Liu, J.; Ma, Q.; Zhuo, Z.; Chen, H.; Zhou, L.; Yang, S.; Zheng, L.; Ning, C.; et al. Gallic acid disruption of A $\beta 1-42$ aggregation rescues cognitive decline of APP/PS1 double transgenic mouse. Neurobiol. Dis. 2019, 124, 67-80. [CrossRef]

54. Gerzson, M.F.B.; Bona, N.P.; Soares, M.S.P.; Teixeira, F.C.; Rahmeier, F.L.; Carvalho, F.B.; da Cruz Fernandes, M.; Onzi, G.; Lenz, G.; Gonçales, R.A.; et al. Tannic Acid Ameliorates STZ-Induced Alzheimer's Disease-Like Impairment of Memory, Neuroinflammation, Neuronal Death and Modulates Akt Expression. Neurotox. Res. 2020, 37, 1009-1017. [CrossRef] [PubMed]

55. Naghizadeh, B.; Mansouri, M.T. Protective Effects of Gallic Acid against Streptozotocin-induced Oxidative Damage in Rat Striatum. Drug Res. 2015, 65, 515-520. [CrossRef]

56. Oyagbemi, A.A.; Omobowale, T.O.; Saba, A.B.; Olowu, E.R.; Dada, R.O.; Akinrinde, A.S. Gallic Acid Ameliorates Cyclophosphamide-Induced Neurotoxicity in Wistar Rats Through Free Radical Scavenging Activity and Improvement in Antioxidant Defense System. J. Diet. Suppl. 2016, 13, 402-419. [CrossRef] [PubMed]

57. Goudarzi, M.; Mombeini, M.A.; Fatemi, I.; Aminzadeh, A.; Kalantari, H.; Nesari, A.; Najafzadehvarzi, H.; Mehrzadi, S. Neuroprotective effects of Ellagic acid against acrylamide-induced neurotoxicity in rats. Neurol. Res. 2019, 41, 419-428. [CrossRef] [PubMed]

58. Ogunlade, B.; Adelakun, S.A.; Agie, J.A. Nutritional supplementation of gallic acid ameliorates Alzheimer-type hippocampal neurodegeneration and cognitive impairment induced by aluminum chloride exposure in adult Wistar rats. Drug Chem. Toxicol. 2020, 1-12. [CrossRef] [PubMed]

59. Fetoni, A.R.; Paciello, F.; Rolesi, R.; Eramo, S.L.M.; Mancuso, C.; Troiani, D.; Paludetti, G. Rosmarinic acid up-regulates the noise-activated Nrf2/HO-1 pathway and protects against noise-induced injury in rat cochlea. Free Radic. Biol. Med. 2015, 85, 269-281. [CrossRef]

60. Lee, A.Y.; Wu, T.T.; Hwang, B.R.; Lee, J.; Lee, M.-H.; Lee, S.; Cho, E.J. The Neuro-Protective Effect of the Methanolic Extract of Perilla frutescens var. japonicaand Rosmarinic Acid against $\mathrm{H}_{2} \mathrm{O}_{2}$-Induced Oxidative Stress in C6 Glial Cells. Biomol. Ther. 2016, 24, 338-345. [CrossRef] [PubMed]

61. De Mello Andrade, J.M.; Dos Santos Passos, C.; Kieling Rubio, M.A.; Mendonça, J.N.; Lopes, N.P.; Henriques, A.T. Combining in vitro and in silico approaches to evaluate the multifunctional profile of rosmarinic acid from Blechnum brasiliense on targets related to neurodegeneration. Chem. Biol. Interact. 2016, 254, 135-145. [CrossRef]

62. Shang, A.-J.; Yang, Y.; Wang, H.-Y.; Tao, B.-Z.; Wang, J.; Wang, Z.-F.; Zhou, D.-B. Spinal cord injury effectively ameliorated by neuroprotective effects of rosmarinic acid. Nutr. Neurosci. 2017, 20, 172-179. [CrossRef] [PubMed]

63. Shan, Y.; Wang, D.-D.; Xu, Y.-X.; Wang, C.; Cao, L.; Liu, Y.-S.; Zhu, C.-Q. Aging as a Precipitating Factor in Chronic Restraint Stress-Induced Tau Aggregation Pathology, and the Protective Effects of Rosmarinic Acid. J. Alzheimers Dis. 2016, 49, 829-844. [CrossRef] [PubMed]

64. Hwang, E.-S.; Kim, H.-B.; Choi, G.-Y.; Lee, S.; Lee, S.-O.; Kim, S.; Park, J.-H. Acute rosmarinic acid treatment enhances long-term potentiation, BDNF and GluR-2 protein expression, and cell survival rate against scopolamine challenge in rat organotypic hippocampal slice cultures. Biochem. Biophys. Res. Commun. 2016, 475, 44-50. [CrossRef]

65. Ghasemzadeh Rahbardar, M.; Amin, B.; Mehri, S.; Mirnajafi-Zadeh, S.J.; Hosseinzadeh, H. Anti-inflammatory effects of ethanolic extract of Rosmarinus officinalis L. and rosmarinic acid in a rat model of neuropathic pain. Biomed. Pharmacother. 2017, 86, 441-449. [CrossRef] [PubMed]

66. Rosińczuk, J.; Dymarek, R.; Całkosiński, I. Histopathological, ultrastructural, and immunohistochemical assessment of hippocampus structures of rats exposed to TCDD and high doses of tocopherol and acetylsalicylic acid. Biomed. Res. Int. 2015, 2015, 645603. [CrossRef] [PubMed]

67. Blanchard, H.C.; Taha, A.Y.; Rapoport, S.I.; Yuan, Z.-X. Low-dose aspirin (acetylsalicylate) prevents increases in brain PGE2, 15-epilipoxin A4 and 8-isoprostane concentrations in 9 month-old HIV-1 transgenic rats, a model for HIV-1 associated neurocognitive disorders. Prostaglandins Leukot. Essent. Fatty Acids 2015, 96, 25-30. [CrossRef] [PubMed]

68. Yi, X.; Han, Z.; Wang, C.; Zhou, Q.; Lin, J. Statin and Aspirin Pretreatment Are Associated with Lower Neurological Deterioration and Platelet Activity in Patients with Acute Ischemic Stroke. J. Stroke Cerebrovasc. Dis. 2017, 26, 352-359. [CrossRef] [PubMed]

69. Shamsara, A.; Sheibani, V.; Asadi-Shekaari, M.; Nematollahi-Mahani, S.N. Neural like cells and acetyl-salicylic acid alter rat brain structure and function following transient middle cerebral artery occlusion. Biomol. Concepts 2018, 9, 155-168. [CrossRef] [PubMed]

70. Roehrich, M.-E.; Wyss, J.-C.; Kumar, R.; Pascual, M.; Golshayan, D.; Vassalli, G. Additive effects of rapamycin and aspirin on dendritic cell allostimulatory capacity. Immunopharmacol. Immunotoxicol. 2015, 37, 434-441. [CrossRef]

71. Xu, Y.X.; Du, F.; Jiang, L.R.; Gong, J.; Zhou, Y.-F.; Luo, Q.Q.; Qian, Z.M.; Ke, Y. Effects of aspirin on expression of iron transport and storage proteins in BV-2 microglial cells. Neurochem. Int. 2015, 91, 72-77. [CrossRef] 
72. Tüzmen, M.N.; Yücel, N.C.; Kalburcu, T.; Demiryas, N. Effects of curcumin and tannic acid on the aluminum- and lead-induced oxidative neurotoxicity and alterations in NMDA receptors. Toxicol. Mech. Methods 2015, 25, 120-127. [CrossRef]

73. Ashafaq, M.; Tabassum, H.; Vishnoi, S.; Salman, M.; Raisuddin, S.; Parvez, S. Tannic acid alleviates lead acetate-induced neurochemical perturbations in rat brain. Neurosci. Lett. 2016, 617, 94-100. [CrossRef] [PubMed]

74. Sen, H.M.; Ozkan, A.; Guven, M.; Akman, T.; Aras, A.B.; Sehitoglu, I.; Alacam, H.; Silan, C.; Cosar, M.; Ozisik Karaman, H.I. Effects of tannic acid on the ischemic brain tissue of rats. Inflammation 2015, 38, 1624-1630. [CrossRef]

75. Ashafaq, M.; Tabassum, H.; Parvez, S. Modulation of behavioral deficits and neurodegeneration by tannic acid in experimental stroke challenged wistar rats. Mol. Neurobiol. 2017, 54, 5941-5951. [CrossRef] [PubMed]

76. Guan, S.; Bao, Y.-M.; Jiang, B.; An, L.-J. Protective effect of protocatechuic acid from Alpinia oxyphylla on hydrogen peroxideinduced oxidative PC12 cell death. Eur. J. Pharmacol. 2006, 538, 73-79. [CrossRef] [PubMed]

77. Guan, S.; Jiang, B.; Bao, Y.M.; An, L.J. Protocatechuic acid suppresses MPP+ -induced mitochondrial dysfunction and apoptotic cell death in PC12 cells. Food Chem. Toxicol. 2006, 44, 1659-1666. [CrossRef]

78. Liu, Y.-M.; Jiang, B.; Bao, Y.-M.; An, L.-J. Protocatechuic acid inhibits apoptosis by mitochondrial dysfunction in rotenone-induced PC12 cells. Toxicol. In Vitro 2008, 22, 430-437. [CrossRef]

79. Zhang, Z.; Li, G.; Szeto, S.S.W.; Chong, C.M.; Quan, Q.; Huang, C.; Cui, W.; Guo, B.; Wang, Y.; Han, Y.; et al. Examining the neuroprotective effects of protocatechuic acid and chrysin on in vitro and in vivo models of Parkinson disease. Free Radic. Biol. Med. 2015, 84, 331-343. [CrossRef] [PubMed]

80. Wang, H.-Y.; Wang, H.; Wang, J.-H.; Wang, Q.; Ma, Q.-F.; Chen, Y.-Y. Protocatechuic Acid Inhibits Inflammatory Responses in LPS-Stimulated BV2 Microglia via NF-KB and MAPKs Signaling Pathways. Neurochem. Res. 2015, 40, 1655-1660. [CrossRef] [PubMed]

81. Semaming, Y.; Sripetchwandee, J.; Sa-Nguanmoo, P.; Pintana, H.; Pannangpetch, P.; Chattipakorn, N.; Chattipakorn, S.C. Protocatechuic acid protects brain mitochondrial function in streptozotocin-induced diabetic rats. Appl. Physiol. Nutr. Metab. 2015, 40, 1078-1081. [CrossRef]

82. Winter, A.N.; Brenner, M.C.; Punessen, N.; Snodgrass, M.; Byars, C.; Arora, Y.; Linseman, D.A. Comparison of the Neuroprotective and Anti-Inflammatory Effects of the Anthocyanin Metabolites, Protocatechuic Acid and 4-Hydroxybenzoic Acid. Oxid. Med. Cell. Longev. 2017, 2017, 6297080. [CrossRef] [PubMed]

83. Li, Z.; Liu, Y.; Wang, F.; Gao, Z.; Elhefny, M.A.; Habotta, O.A.; Abdel Moneim, A.E.; Kassab, R.B. Neuroprotective effects of protocatechuic acid on sodium arsenate induced toxicity in mice: Role of oxidative stress, inflammation, and apoptosis. Chem. Biol. Interact. 2021, 337, 109392. [CrossRef]

84. Hornedo-Ortega, R.; Álvarez-Fernández, M.A.; Cerezo, A.B.; Richard, T.; Troncoso, A.M.A.; Garcia-Parrilla, M.A.C. Protocatechuic Acid: Inhibition of Fibril Formation, Destabilization of Preformed Fibrils of Amyloid- $\beta$ and $\alpha$-Synuclein, and Neuroprotection. J. Agric. Food Chem. 2016, 64, 7722-7732. [CrossRef]

85. Scalbert, A.; Williamson, G. Dietary intake and bioavailability of polyphenols. J. Nutr. 2000, 130, 2073S-2085S. [CrossRef] [PubMed]

86. Guven, M.; Yuksel, Y.; Sehitoglu, M.H.; Tokmak, M.; Aras, A.B.; Akman, T.; Golge, U.H.; Goksel, F.; Karavelioglu, E.; Cosar, M. The Effect of Coumaric Acid on Ischemia-Reperfusion Injury of Sciatic Nerve in Rats. Inflammation 2015, 38, 2124-2132. [CrossRef]

87. Guven, M.; Sehitoglu, M.H.; Yuksel, Y.; Tokmak, M.; Aras, A.B.; Akman, T.; Golge, U.H.; Karavelioglu, E.; Bal, E.; Cosar, M. The neuroprotective effect of coumaric acid on spinal cord ischemia/reperfusion injury in rats. Inflammation 2015, 38, 1986-1995. [CrossRef] [PubMed]

88. Guven, M.; Aras, A.B.; Akman, T.; Sen, H.M.; Ozkan, A.; Salis, O.; Sehitoglu, I.; Kalkan, Y.; Silan, C.; Deniz, M.; et al. Neuroprotective effect of p-coumaric acid in rat model of embolic cerebral ischemia. Iran. J. Basic Med. Sci. 2015, 18, 356-363.

89. Sakamula, R.; Thong-Asa, W. Neuroprotective effect of p-coumaric acid in mice with cerebral ischemia reperfusion injuries. Metab. Brain Dis. 2018, 33, 765-773. [CrossRef]

90. Daroi, P.A.; Dhage, S.N.; Juvekar, A.R. p-Coumaric acid mitigates lipopolysaccharide induced brain damage via alleviating oxidative stress, inflammation and apoptosis. J. Pharm. Pharmacol. 2021, 20, rgab077. [CrossRef]

91. Oh, D.-R.; Kim, M.-J.; Choi, E.-J.; Kim, Y.; Lee, H.-S.; Bae, D.; Choi, C. Protective Effects of p-Coumaric Acid Isolated from Vaccinium bracteatum Thunb. Leaf Extract on Corticosterone-Induced Neurotoxicity in SH-SY5Y Cells and Primary Rat Cortical Neurons. Processes 2021, 9, 869. [CrossRef]

92. Shin, D.-S.; Kim, K.W.; Chung, H.Y.; Yoon, S.; Moon, J.-O. Effect of sinapic acid against carbon tetrachloride-induced acute hepatic injury in rats. Arch. Pharm. Res. 2013, 36, 626-633. [CrossRef] [PubMed]

93. Lee, H.E.; Kim, D.H.; Park, S.J.; Kim, J.M.; Lee, Y.W.; Jung, J.M.; Lee, C.H.; Hong, J.G.; Liu, X.; Cai, M.; et al. Neuroprotective effect of sinapic acid in a mouse model of amyloid $\beta(1-42)$ protein-induced Alzheimer's disease. Pharmacol. Biochem. Behav. 2012, 103, 260-266. [CrossRef] [PubMed]

94. Zare, K.; Eidi, A.; Roghani, M.; Rohani, A.H. The neuroprotective potential of sinapic acid in the 6-hydroxydopamine-induced hemi-parkinsonian rat. Metab. Brain Dis. 2015, 30, 205-213. [CrossRef]

95. Kim, Y.-O.; Lee, S.-W.; Oh, M.-S.; Lee, H.J. Effects of sinapic Acid of 4 vessel occlusion model-induced ischemia and cognitive impairments in the rat. Clin. Psychopharmacol. Neurosci. 2011, 9, 86-90. [CrossRef]

96. Kim, D.H.; Yoon, B.H.; Jung, W.Y.; Kim, J.M.; Park, S.J.; Park, D.H.; Huh, Y.; Park, C.; Cheong, J.H.; Lee, K.-T.; et al. Sinapic acid attenuates kainic acid-induced hippocampal neuronal damage in mice. Neuropharmacology 2010, 59, 20-30. [CrossRef] 
97. Jha, A.B.; Panchal, S.S.; Shah, A. Ellagic acid: Insights into its neuroprotective and cognitive enhancement effects in sporadic Alzheimer's disease. Pharmacol. Biochem. Behav. 2018, 175, 33-46. [CrossRef]

98. Mansouri, M.T.; Farbood, Y.; Naghizadeh, B.; Shabani, S.; Mirshekar, M.A.; Sarkaki, A. Beneficial effects of ellagic acid against animal models of scopolamine- and diazepam-induced cognitive impairments. Pharm. Biol. 2016, 54, 1947-1953. [CrossRef]

99. Liu, Q.-S.; Li, S.-R.; Li, K.; Li, X.; Yin, X.; Pang, Z. Ellagic acid improves endogenous neural stem cells proliferation and neurorestoration through Wnt/ $\beta$-catenin signaling in vivo and in vitro. Mol. Nutr. Food Res. 2017, 61, 1600587. [CrossRef]

100. Farbood, Y.; Sarkaki, A.; Dolatshahi, M.; Taqhi Mansouri, S.M.; Khodadadi, A. Ellagic Acid Protects the Brain Against 6Hydroxydopamine Induced Neuroinflammation in a Rat Model of Parkinson's Disease. Basic Clin. Neurosci. $2015,6,83-89$.

101. Chen, S.-Y.; Zheng, K.; Wang, Z. Neuroprotective effects of Ellagic acid on Neonatal Hypoxic Brain Injury via Inhibition of Inflammatory Mediators and Down-regulation of JNK/p38 MAPK Activation. Trop. J. Pharm. Res. 2016, 15, 241. [CrossRef]

102. Thrash-Williams, B.; Karuppagounder, S.S.; Bhattacharya, D.; Ahuja, M.; Suppiramaniam, V.; Dhanasekaran, M. Methamphetamineinduced dopaminergic toxicity prevented owing to the neuroprotective effects of salicylic acid. Life Sci. 2016, 154, 24-29. [CrossRef] [PubMed]

103. Cetin, D.; Hacimuftuoglu, A.; Tatar, A.; Turkez, H.; Togar, B. The in vitro protective effect of salicylic acid against paclitaxel and cisplatin-induced neurotoxicity. Cytotechnology 2016, 68, 1361-1367. [CrossRef]

104. Lambert, G.W.; Eisenhofer, G.; Jennings, G.L.; Esler, M.D. Regional homovanillic acid production in humans. Life Sci. 1993, 53, 63-75. [CrossRef]

105. Ibero-Baraibar, I.; Perez-Cornago, A.; Ramirez, M.J.; Martínez, J.A.; Zulet, M.A. An Increase in Plasma Homovanillic Acid with Cocoa Extract Consumption Is Associated with the Alleviation of Depressive Symptoms in Overweight or Obese Adults on an Energy Restricted Diet in a Randomized Controlled Trial. J. Nutr. 2015, 146, 897S-904S. [CrossRef] [PubMed]

106. Van de Kerkhof, N.W.A.; Fekkes, D.; van der Heijden, F.M.M.A.; Egger, J.I.M.; Verhoeven, W.M.A. Relationship between plasma homovanillic acid and outcome in patients with psychosis spectrum disorders. Neuropsychobiology 2015, 71, 212-217. [CrossRef]

107. Neider, D.; Lindström, L.H.; Bodén, R. Risk factors for suicide among patients with schizophrenia: A cohort study focused on cerebrospinal fluid levels of homovanillic acid and 5-hydroxyindoleacetic acid. Neuropsychiatr. Dis. Treat. 2016, 12, 1711-1714. [CrossRef]

108. Rob, M.M.; Hossen, K.; Iwasaki, A.; Suenaga, K.; Kato-Noguchi, H. Phytotoxic Activity and Identification of Phytotoxic Substances from Schumannianthus dichotomus. Plants 2020, 9, 102. [CrossRef]

109. Güven, M.; Aras, A.B.; Topaloğlu, N.; Özkan, A.; Şen, H.M.; Kalkan, Y.; Okuyucu, A.; Akbal, A.; Gökmen, F.; Coşar, M. The protective effect of syringic acid on ischemia injury in rat brain. Turk. J. Med. Sci. 2015, 45, 233-240. [CrossRef]

110. Tokmak, M.; Yuksel, Y.; Sehitoglu, M.H.; Guven, M.; Akman, T.; Aras, A.B.; Cosar, M.; Abbed, K.M. The neuroprotective effect of syringic acid on spinal cord ischemia/reperfusion injury in rats. Inflammation 2015, 38, 1969-1978. [CrossRef]

111. Cao, Y.; Zhang, L.; Sun, S.; Yi, Z.; Jiang, X.; Jia, D. Neuroprotective effects of syringic acid against OGD/R-induced injury in cultured hippocampal neuronal cells. Int. J. Mol. Med. 2016, 38, 567-573. [CrossRef]

112. Rashedinia, M.; Alimohammadi, M.; Shalfroushan, N.; Khoshnoud, M.J.; Mansourian, M.; Azarpira, N.; Sabahi, Z. Neuroprotective effect of syringic acid by modulation of oxidative stress and mitochondrial mass in diabetic rats. BioMed Res. Int. 2020, 2020, 8297984. [CrossRef]

113. Ogut, E.; Akcay, G.; Yildirim, F.B.; Derin, N.; Aslan, M. The influence of syringic acid treatment on total dopamine levels of the hippocampus and on cognitive behavioral skills. Int. J. Neurosci. 2020, 1-9. [CrossRef] [PubMed]

114. Zhao, Y.; Dang, M.; Zhang, W.; Lei, Y.; Ramesh, T.; Priya Veeraraghavan, V.; Hou, X. Neuroprotective effects of Syringic acid against aluminium chloride induced oxidative stress mediated neuroinflammation in rat model of Alzheimer's disease. J. Funct. Foods 2020, 71, 104009. [CrossRef]

115. Song, M.; Du, Z.; Lu, G.; Li, P.; Wang, L. Syringic acid protects retinal ganglion cells against H2O2-induced apoptosis through the activation of PI3K/Akt signaling pathway. Cell. Mol. Biol. 2016, 62, 50-54. [PubMed]

116. Vargas-Tah, A.; Gosset, G. Production of Cinnamic and p-Hydroxycinnamic Acids in Engineered Microbes. Front. Bioeng. Biotechnol. 2015, 3, 116. [CrossRef]

117. Bae, W.-Y.; Choi, J.-S.; Jeong, J.-W. The neuroprotective effects of cinnamic aldehyde in an MPTP mouse model of parkinson's disease. Int. J. Mol. Sci. 2018, 19, 551. [CrossRef] [PubMed]

118. Zhao, J.; Zhang, X.; Dong, L.; Wen, Y.; Zheng, X.; Zhang, C.; Chen, R.; Zhang, Y.; Li, Y.; He, T.; et al. Cinnamaldehyde inhibits inflammation and brain damage in a mouse model of permanent cerebral ischaemia. Br. J. Pharmacol. 2015, 172, 5009-5023. [CrossRef] [PubMed]

119. Gürer, B.; Kertmen, H.; Kuru Bektaşoğlu, P.; Öztürk, Ö.Ç.; Bozkurt, H.; Karakoç, A.; Arıkök, A.T.; Çelikoğlu, E. The effects of Cinnamaldehyde on early brain injury and cerebral vasospasm following experimental subarachnoid hemorrhage in rabbits. Metab. Brain Dis. 2019, 34, 1737-1746. [CrossRef]

120. Emamghoreishi, M.; Farrokhi, M.R.; Amiri, A.; Keshavarz, M. The neuroprotective mechanism of cinnamaldehyde against amyloid- $\beta$ in neuronal SHSY5Y cell line: The role of N-methyl-D-aspartate, ryanodine, and adenosine receptors and glycogen synthase kinase-3ß. Avicenna J. Phytomed. 2019, 9, 271-280.

121. Rashidi, R.; Moallem, S.A.; Moshiri, M.; Hadizadeh, F.; Etemad, L. Protective Effect of Cinnamaldehyde on METH-induced Neurotoxicity in PC12 Cells via Inhibition of Apoptotic Response and Oxidative Stress. Iran. J. Pharm. Res. 2021, 20, 135-143. [CrossRef] [PubMed] 
122. Pan, Z.; He, X.; Zhou, X.; Li, X.; Rong, B.; Wang, F. Combination of ellagic acid and trans-cinnamaldehyde alleviates aging-induced cognitive impairment via modulation of mitochondrial function and inflammatory and apoptotic mediators in the prefrontal cortex of aged rats. Chin. J. Physiol. 2020, 63, 218-226. [CrossRef] [PubMed]

123. Kuru Bektaşoğlu, P.; Koyuncuoğlu, T.; Demir, D.; Sucu, G.; Akakın, D.; Peker Eyüboğlu, İ.; Yüksel, M.; Çelikoğlu, E.; Yeğen, B.Ç.; Gürer, B. Neuroprotective effect of cinnamaldehyde on secondary brain injury after traumatic brain injury in a rat model. World Neurosurg. 2021, 153, e392-e402. [CrossRef] [PubMed]

124. Etaee, F.; Komaki, A.; Faraji, N.; Rezvani-Kamran, A.; Komaki, S.; Hasanein, P.; Taheri, M.; Omidi, G. The effects of cinnamaldehyde on acute or chronic stress-induced anxiety-related behavior and locomotion in male mice. Stress 2019, 22, 358-365. [CrossRef]

125. Thomford, N.E.; Senthebane, D.A.; Rowe, A.; Munro, D.; Seele, P.; Maroyi, A.; Dzobo, K. Natural products for drug discovery in the 21st century: Innovations for novel drug discovery. Int. J. Mol. Sci. 2018, 19, 1578. [CrossRef]

126. Caruso, G.; Musso, N.; Grasso, M.; Costantino, A.; Lazzarino, G.; Tascedda, F.; Gulisano, M.; Lunte, S.M.; Caraci, F. Microfluidics as a novel tool for biological and toxicological assays in drug discovery processes: Focus on microchip electrophoresis. Micromachines 2020, 11, 593. [CrossRef] [PubMed]

127. Chen, J.; Yang, J.; Ma, L.; Li, J.; Shahzad, N.; Kim, C.K. Structure-antioxidant activity relationship of methoxy, phenolic hydroxyl, and carboxylic acid groups of phenolic acids. Sci. Rep. 2020, 10, 2611. [CrossRef]

128. Kumar, N.; Goel, N. Phenolic acids: Natural versatile molecules with promising therapeutic applications. Biotechnol. Rep. 2019, 24, e00370. [CrossRef] 